\title{
The Siamese Concept of Muslims through Mural Paintings
}

\author{
Adis Idris Raksamani \\ (อาดิศร์ อิดรีส รักษมณี) \\ Instructor, Faculty of Engineering and Architecture, Rajamangala University \\ of Technology Suvarnabhumi, Nonthaburi, Thailand \\ adis_idris@hotmail.com
}

\begin{abstract}
The objective of this study is to examine the purpose and meaning of portrayals of Muslims in the Thai traditional art and architecture of temples and palaces. The focus is on the Siamese concepts of Muslims and the features of Muslims that Siamese people in the past intended to communicate to Siamese society. The study deals with the concept and design of painting found in Thai traditional mural paintings. The findings reveal that the portrayals of Muslims in the mural paintings represent the symbolic meanings which can be traced according 4 chronicle stages as follows:

1. The otherness of Muslims from afar in the late Ayutthaya.

2. The trace of Islamic civilization in the end of Ayutthaya, the Thonburi and the Reigns of King Rama I-II.

3. The multicultural guests in the Reigns of King Rama III-IV.

4. Unity under the royal patronage in the Reigns of King Rama V-VI.

The benefit of the research can be applied to enhance the good relationship and understanding among different cultures in Thai society.
\end{abstract}

\section{Keywords}

concepts - Muslim - Siam - mural painting - architecture 


\section{บุทคัดย่อ \\ มโนทัศนชองชาวสยามที่มีต่อมุสลิมผ่านทางจิตรกรรมฝาผนัง}

งานวิจัยนี้มุ่งศึกษาวัตถุประสงค์และความหมายของภาพมุสลิมในจิตรกรรมไทย ประเพณีในสถาปัตยกรรมประเภทวัดและวัง และศึกษามโนทัศน์ของชาวสยาม ที่มีต่อมุสลิมที่ชาวสยามต้องการถ่ายทอดสู่สังคม ผ่านทางการศึกษาแนวคิดและ รูปแบบของภาพมุสลิมในจิตรกรรม ตลอดจนศึกษาลักษณะของสถาปัตยกรรมที่ สัมพันธ์กับการนำเสนอเนื้อหาในงานจิตรกรรม ได้แบ่งเนื้อหาตามลำดับเวลาไว้ 4 ช่วง โดยพิจารณาจากความต่อเนื่องและการเปลี่ยนแปลงทางด้านความคิดที่มีผล ต่องานจิตรกรรม ผลการศึกษาพบว่าภาพจิตรกรรมฝูาผนังเป็นงานศิลปะที่ถ่ายทอด เรื่องราวและวิธีคิดของช่างเขียนและผู้อุปถัมภ์การสร้างวัดที่สืบทอดกันมา เนื้อหา ในภาพจิตรกรรมประเพณีจึงแสดงความเป็นมาของมุสลิมในสังคมพหุวัฒนธรรม ผ่านทางประวัติศาสตร์ศิลปะและสถาปัตยกรรมในสยามและสะท้อนโลกทัศน์ของ ชาวสยามที่มีต่อมุสลิมในแง่มุมต่างๆ ภายใต้เงื่อนไขทางสังคมและปัจจัยแวดล้อมที่ แปรเปลี่ยนตามยุคสมัย ดังนี้

ช่วงที่ 1 มุสลิมในฐานะแขกจากแดนไกลในสมัยกรุงศรีอยุธยาตอนปลาย ช่วงที่ 2 ร่องรอยอารยธรรมอิสลามในสมัยกรุงศรีอยุธยาตอนปลาย สมัยกรุงธนบุรี สมัยรัตนโกสินทร์ตอนต้นระหว่างรัชกาลที่ $1-$ รัชกาลที่ 2

ช่วงที่ 3 อาคันตุกะต่างวัฒนธรรมในสมัยรัตนโกสินทร์ ระหว่างรัชกาลที่ 3 - รัชกาล ที่ 4

ช่วงที่ 4 เอกภาพใต้พระบรมโพธิสมภารในสมัยรัตนโกสินทร์ ระหว่างรัชกาลที่ $5-$ รัชกาลที่ 6

องค์ความรู้ดังกล่าวสามารถใช้เป็นแนวทางในการอยู่ร่วมกันด้วยความเข้าใจอันดี ระหว่างกลุมชนต่างวัฒนธรรมในสังคมไทย ซึ่งเป็นพื้นฐานสำคัญสู่การพัฒนาสังคม แบบบูรณาการอย่างยั่งยืนบนพื้นฐานของภูมิปัญญาท้องถิ่นและศิลปวัฒนธรรมใน อนาคต

\section{$1 \quad$ Introduction 1}

O mankind, indeed we have created you from male and female and made you peoples and tribes that you may know one another. Indeed, the most noble of you in the sight of Allah is the most righteous of you.

AL-QURAN 49:13

1 This article is part of a research report. Raksamani, A. 2014. A Study of Siamese Concepts of Muslims through the Mural Paintings (Research Report), Bangkok: The Thailand Research Fund, Office of the Higher Education Commission and Kasem Bundit University. (in Thai) 
Muslims believe that men are created by god in different groups. Each Muslim group belongs to a brotherhood of humanity called Ummah. They generally practise according to the principles in the Book of Al-Quran and the model of the Prophet in Al-Hadith. The concept of Islamic art is, therefore, based on those principles and models, integrated with the secular concepts in daily life. Theoretically, the concept of Islamic art was originated when the Prophet built a mosque as an architectural site for God worship as well as a center of community, during the Hijrah or emigration of the Prophet from Makkah to Madinah. Faith in God, benefaction, unity and rationality, which are important principles of Islam, were reflected in the architecture. These concepts in Islamic art have been generated in mosque construction throughout Muslim communities.

After the time of the Prophet and the 4 Khalifahs (Caliphs), Islam gradually spread to several lands of various ethnic, cultural, social, geographical, economic and political backgrounds. Civilizations of different backgrounds were integrated into Islamic art whose main concept belongs to "Ummah" or the Islamic nation of brotherhood.

Due to the prohibiting of image worship, the figuring of any human or animal is strictly avoided by Muslim artists. However, this restriction seems to have been overlooked, significantly and uniformly by artists of different cultures.

Apparently, miniature painting began to develop in the Muslim Abbasid Dynasty when scholars translated some valuable textbooks from Greek, Persian and Indian languages into Arabic. Painting style, including costumes and setting in the background, were then adopted and applied to the Islamic context. There is no restrictive rule for Islamic art. The concept of Islamic art is associated with a faith in God and benefaction and religious restriction is also effective in Islamic art. The interpretations of the Ulamas or the scholars were broadened and applied from diverse perspectives. As for human figures, Muslim artists created them in a non-realistic way in surrealistic settings. Islamic paintings were developed in textbooks of many fields, including literary world. Some acclaimed paintings are illustrations of the Persian literary works: Shah Nameh and the Hamza Nameh. ${ }^{2}$

Islamic painting flourished in those territories associated with Islamic culture and this included Siam. Nevertheless, paintings of people and animals rarely appeared in mosques due to religious restrictions but images of Muslims appeared in mural painting in Buddhist temples. As a record of the concept and attitudes of the people in society, there is a significant probability that we

2 Shah Nameh or the Book of the Kings is the national epic of Iran, composed by Firdausi in the tenth century. Hamza Nameh is the story of Hamza, the Prophet's uncle who was a hero of the earliest period of Islam. There were many tales about his daring in battle. (O'Kane, 1972: 241) 


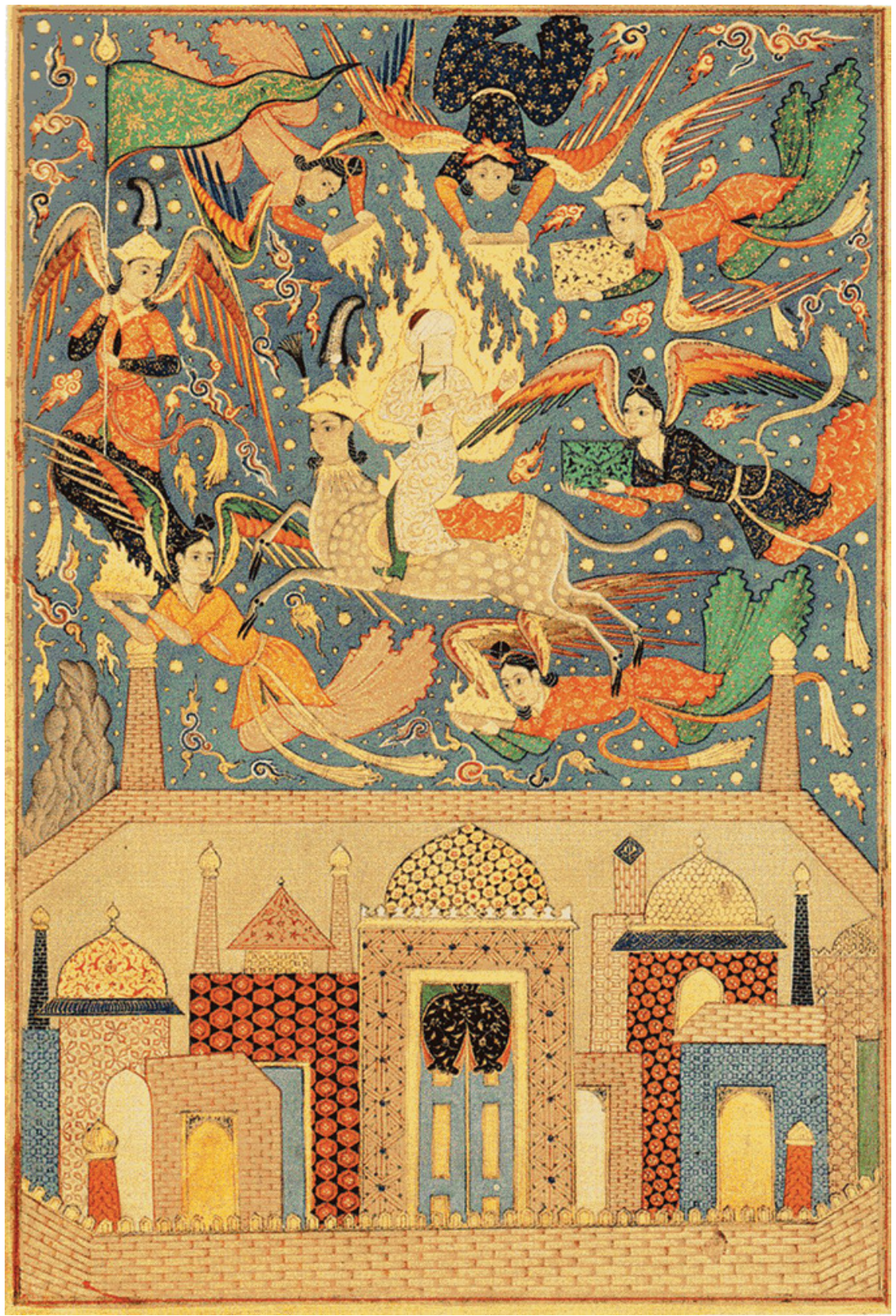

FIGURE 1 The painting of Prophet Muhammad's miraculous night journey from Makkah to the Aqsa mosque in Jerusalem, mounted on Buraq from a Falname manuscript (book of divination) Deccan, Golconda 1610-30. (Khalili, 2008: 79) 


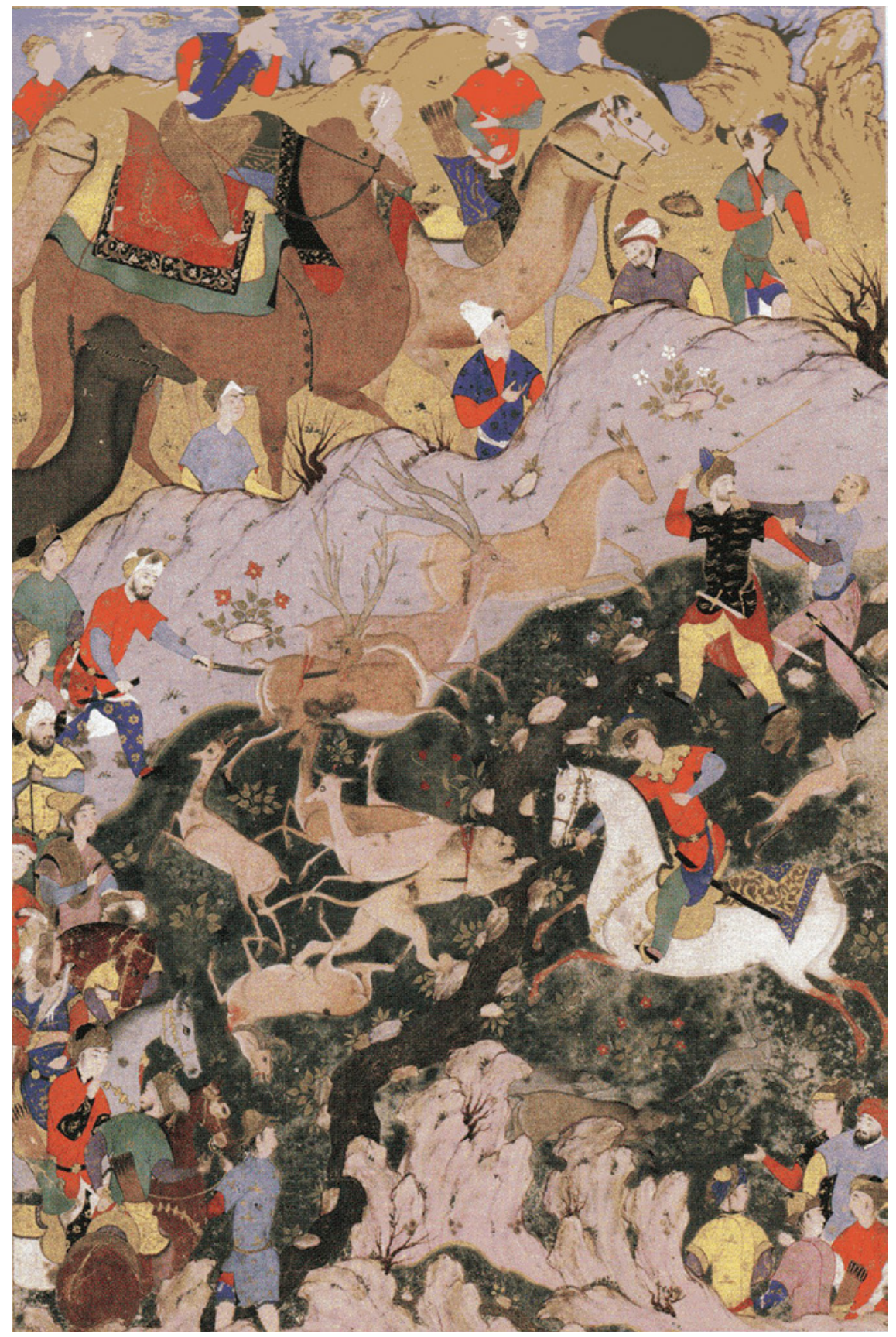

FIGURE 2 A princely hunt, from a Shah Nameh made for Shah Isma'il. Qazvin, 1576-7. (Khalili, 2008: 71) 


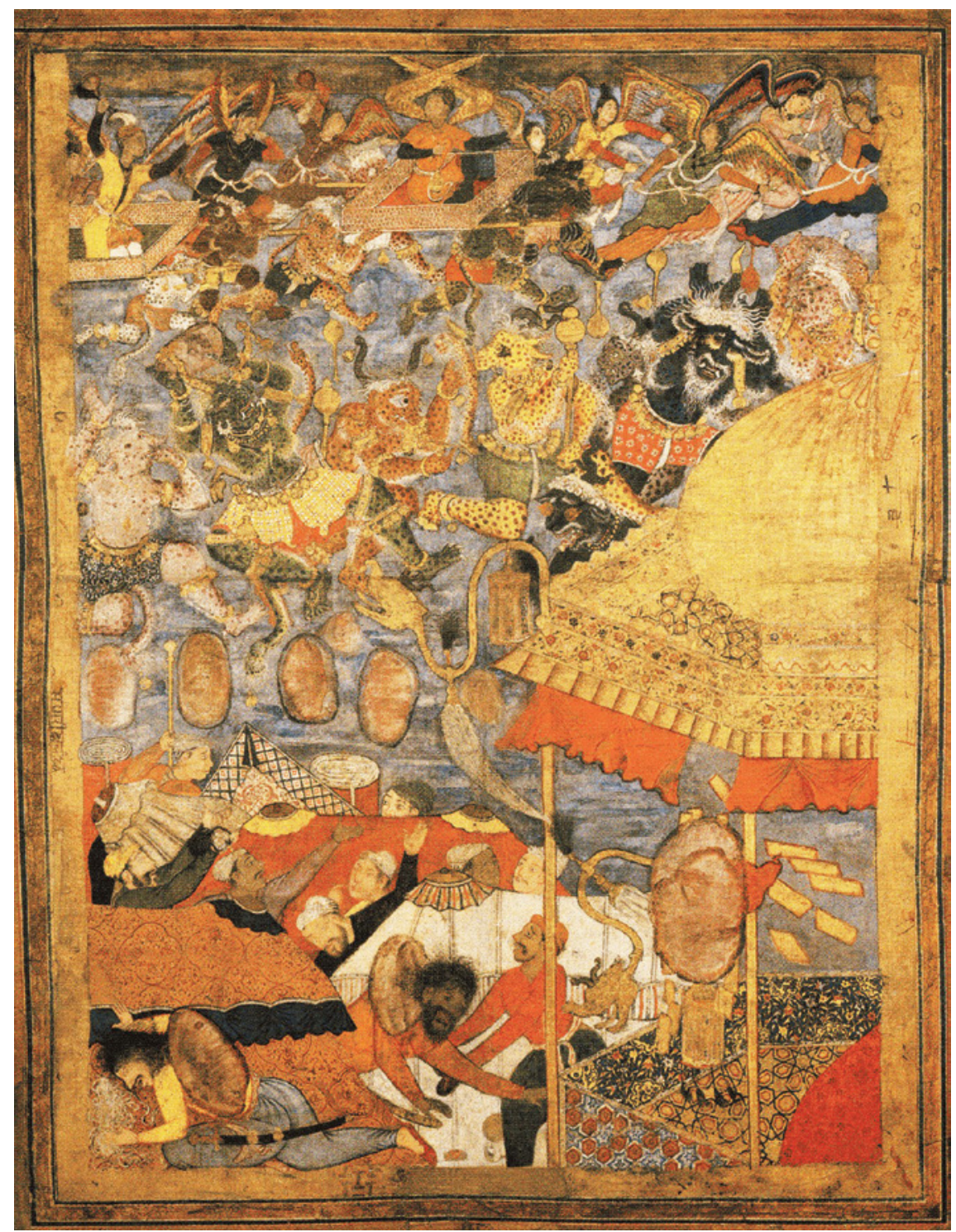

FIGURE 3 Peris (Fairies) destroying an enemy camp from a copy of the Hamza Nameh, Mughal, 1562. (Khalili, 2008: 76 )

can study the Siamese concept of Muslims and the features of Muslims that Siamese people in the past intended to communicate to Siamese society. The objective of this research is to study the purpose and meaning of portrayals of Muslims in Thai traditional art and the architecture of temples and palaces. The result of the research may present the Siamese concepts of Muslims developed in each period. 
Many centuries ago, Islamic culture was introduced to Southeast Asia by Indian, Persian and Arabian merchants. Later, Islam flourished in Southeast Asia including Pattani which became a part of Siam. In Siam, especially Ayutthaya, Muslims from several lands took part in the national development. They were referred to in documents as well as in the colloquial language as "khaek". The original meaning of the word "Khaek", that is used today, is "visitor". Later, it became an additional meaning referring to a visitor from afar, besides "Farang" or a Western white. In general, "Khaek" may be classified by ethnic groups as "Khaek Melayu", "Khaek Java", "Khaek Cham", "Khaek India”, "Khaek Arab", "Khaek Persia"; or by religious distinction such as "Khaek Muslim", "Khaek Brahman", and "Khaek Hindu". In this study, the word "Muslim" is used for "Khaek Muslim" and this includes ethnic Muslims from Arabia, Persia, India, Malaya, Java and Cham.

In the reign of King Naresuan, human resources, especially workers and specialists from several countries were recruited to reconstruct Ayutthaya after its defeat. Later in the reign of King Narai, foreign affairs and international trade

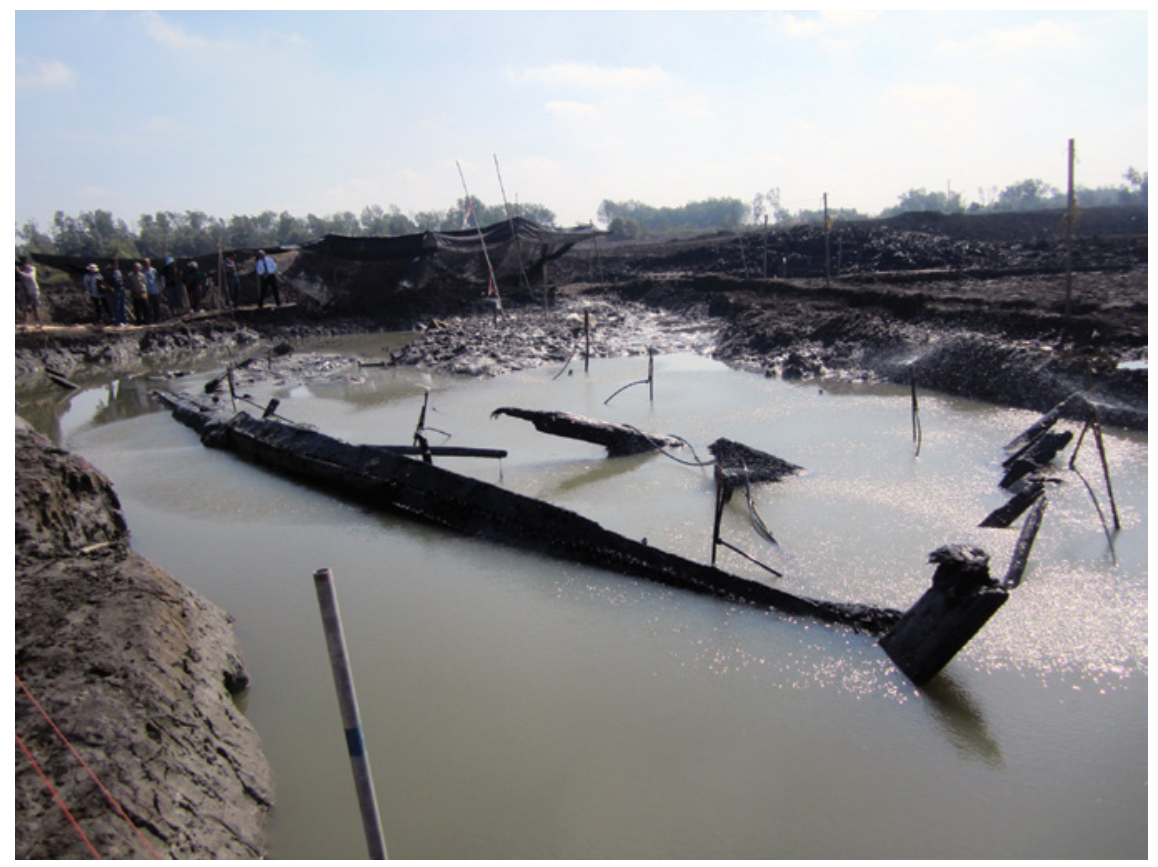

FIGURE 4 A Shipwreck found in Samutsakhon province. According to the Fine Arts department, Ministry of Culture, the ship possibly came from an Arab country 


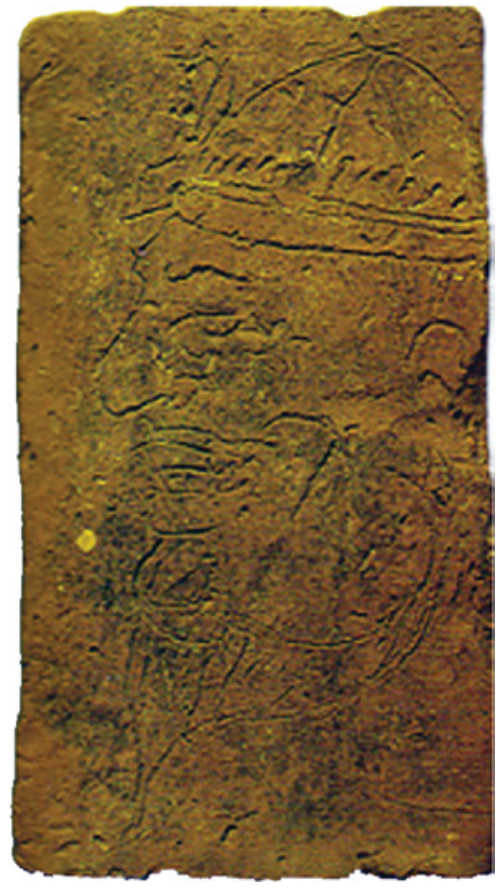

FIGURE 5

The portrait of a man on a brick tile in Davaravati style. The man, with the profile of an Arab, wears a kapiyah cap, widely used in Islamic culture.The brick was found in Chula Pratone Chedi, Nakhon Pathom Province; located at Phra Prathom Chedi National Museum. (Department of Fine Arts, Ministry of Culture)

became the focus. Siam required advanced knowledge and technology to accelerate the national development process. Muslims from neighboring countries, such as Javanese, Malaysian and Cham, migrated to Siam and became a part of the society. Meanwhile, Muslims from overseas who had prospered in international trading had the opportunity to work in the government's commercial and diplomatic offices. Some of them were also assigned to the royal court.

In the late sixteenth century, Ayutthaya was transformed into an important trade emporium with the migration of foreign merchants. Thus the city needed to enforce maritime laws and establish responsibilities for officials dealing with foreigners. (Mascinkowski, 2002:32) Having the privilege of trading and management skills, Chinese and Muslim people had participated in this management. Chinese officials were responsible for Eastern Maritime Affairs called "Krom Tha Sai". Persian officials were responsible for Western Maritime Affairs called "Krom Tha Khwa". The Head of the "Krom Tha Khwa", entitled Chularajamontri, was also responsible for the Muslim communities in Siam. Each community was, in turn, led by an Imam in both secular and religious affairs. 

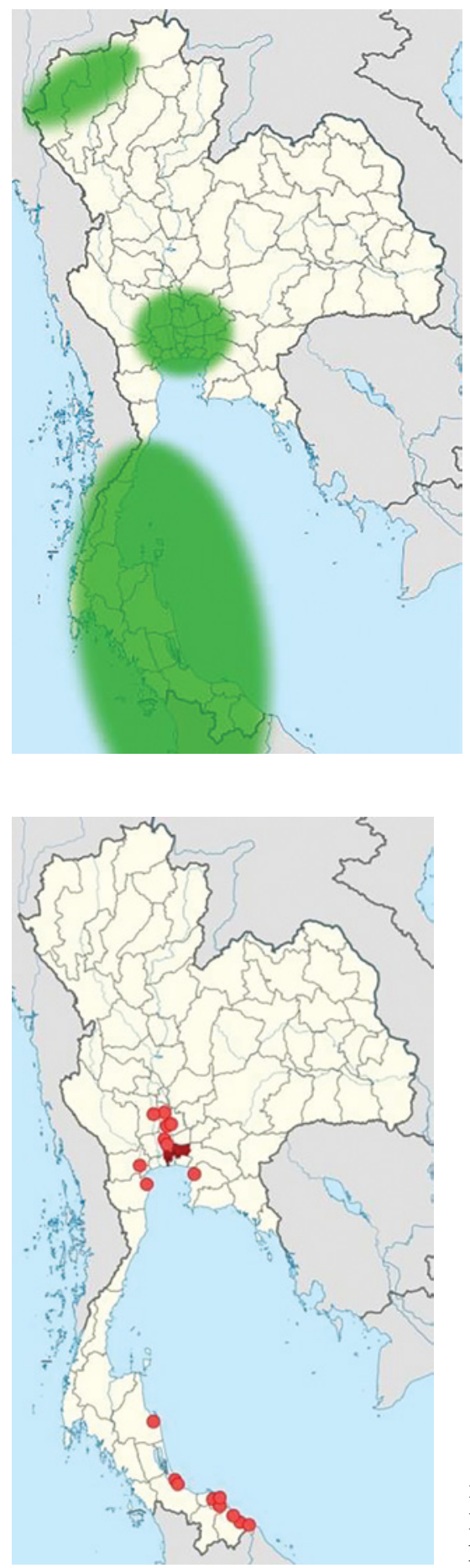

FIGURE 6

Settlement of Muslims in Siam in the past
FIGURE 7

Locations of temples in Siam where paintings of Muslim portrayals have been collected as data 


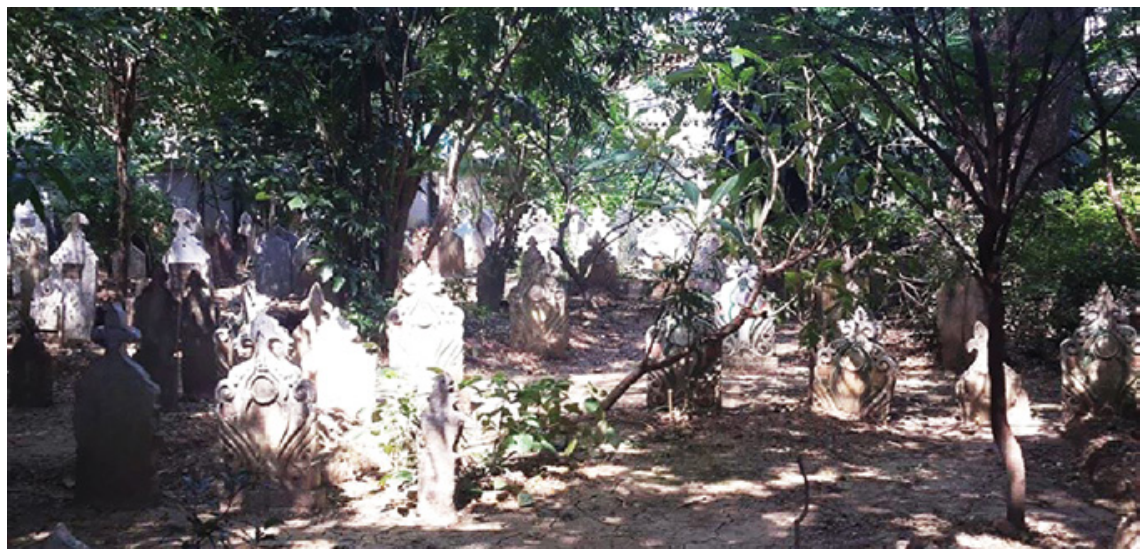

FIGURE 8 The ancient Kubur (cemetery) of Tonson Mosque, Bangkok suggests an old Muslim settlement in Thonburi

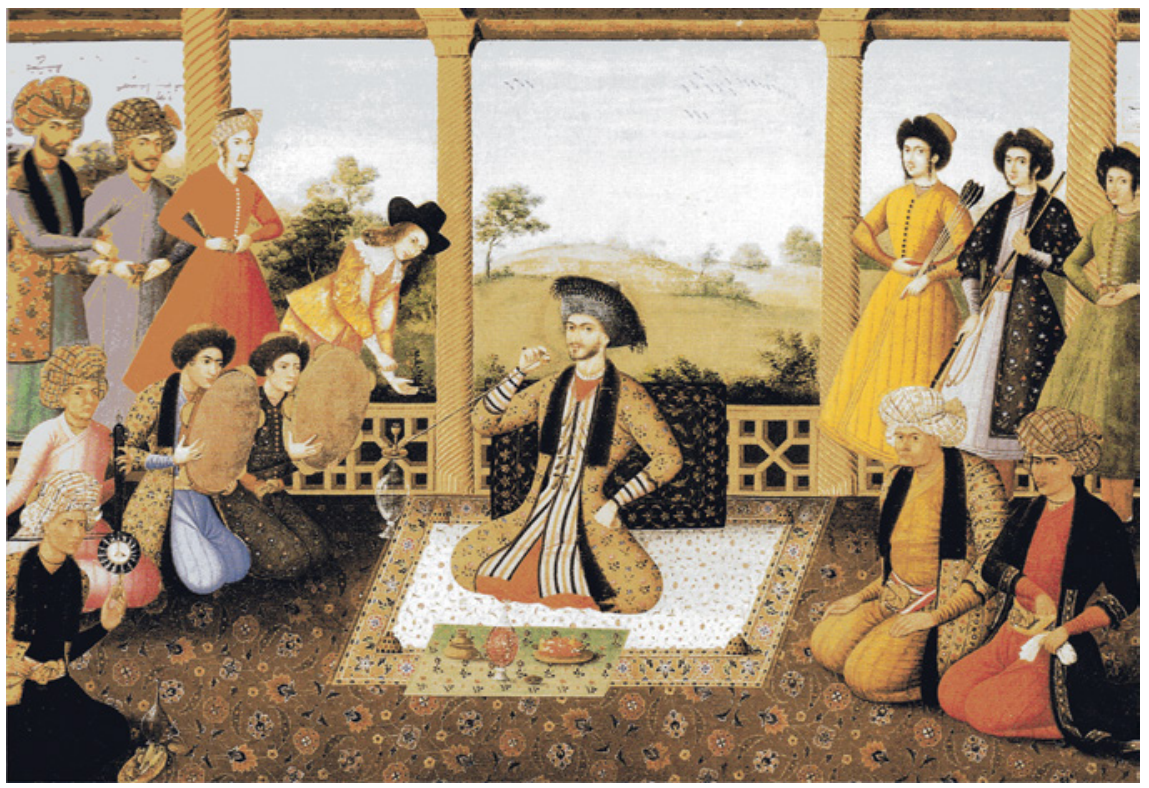

FIGURE 9 Shah Sulaiman of Safavid and his courtiers from Ali Quli Jabadar, Isfahan, 1670. (Niewohner, 2000: 525) 


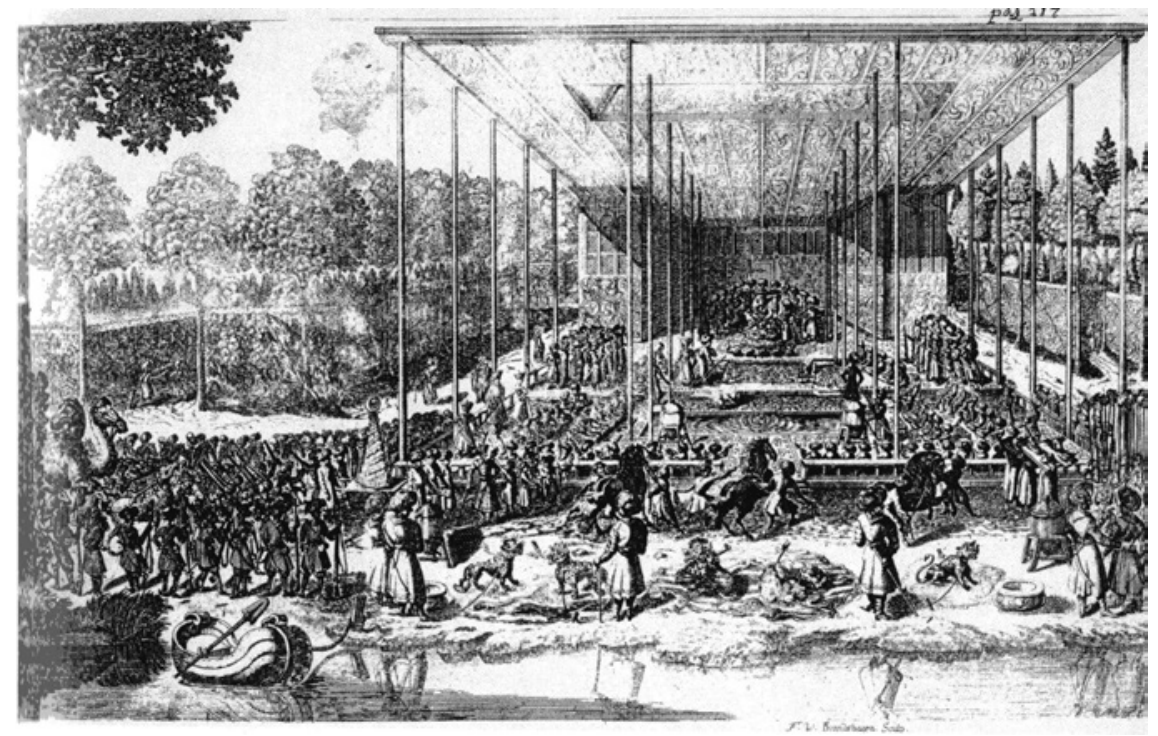

FIgURE 10 In the Safavid Palace, Isfahan Engelbert Kaempfer, Amoenitatum Exotacarum. (Blair and Bloom, 2000: 505)

Muslims in Siam belong to different ethnical and cultural backgrounds which may be classified as follows: 1. Indo-Persian 2. Arabian 3. Malay 4. Chinese 5. Cham-Khmer 6. Javanese 7. Indian, Pakistani and Bengali. Originally, Muslims settled in three main areas of Siam. The first was the southern part of Siam, a settlement of Malay Muslims. The second was Ayutthaya, Thonburi, Bangkok and the vicinity, a settlement of multicultural habitations of Cham, Javanese, Malaysian, Persian Arabian and Indian people. Ayutthaya was then the center where foreign people, including Muslims, participated in developing Siam in various ways. After the Ayutthaya period, some Muslims in Ayutthaya migrated to Thonburi and Bangkok. The third zone was the northern part of Siam, a settlement of Chinese and Indian Muslims.

As a part of the Siamese community, Muslims shared some aspects of Islamic art and culture with the Siamese people. It is worth mentioning Muslim diplomats in King Narai's court who are associated with some stories from the Persian epic, the Book of the King. (O'Kane, 1972:127) They showed illustrations of some Persian artists to the Kings. Also the King was sometimes inclined to wear Iranian clothes. (O'Kane, 1972:99) The courtiers might have been inspired by some figures and aspects in the illustrations. These images of Muslims, then, appeared later in some pieces of art when depicting Muslim figures. 


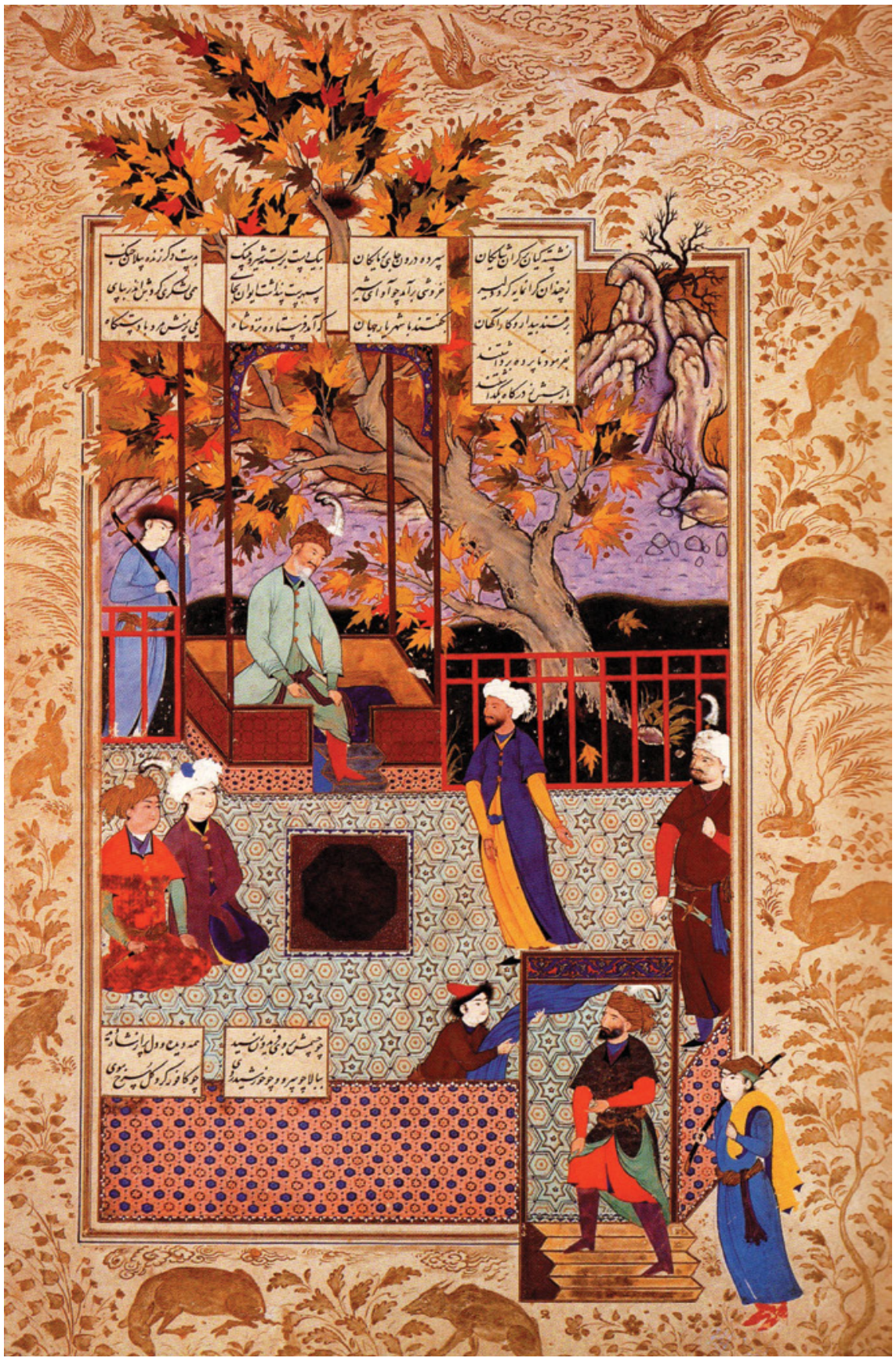

FIGURE 11 Faridun Spurns the Ambassador from Salm and Tur', from a fragmentary Shanameh of Firdausi. (Canby, 2002:104) 
In the traditional Siamese Buddhist community, the temple is a religious center and community activity center. In the past, it was signified as a center of knowledge and social communication. A mural painting in the temple was one of the media used to preach the Dharma along with a sermon to local people. Details in the paintings are noticeable as traces of concepts indicating figures of a different culture.

The physical characteristics of this temple are symbolically designed. The planning and the composition of the temple connotes the site as a model of the universe reflecting the concept of Buddha Spawa (พุทธสภาวะ—Buddha Status). The contents of the traditional mural paintings in the temple mainly describe Buddhist Dharma principles. Mostly, they were created according to the needs and concepts of their aristocratic patrons. Moreover, they reflect the artists' inspiration, based on their traditions and social contexts.

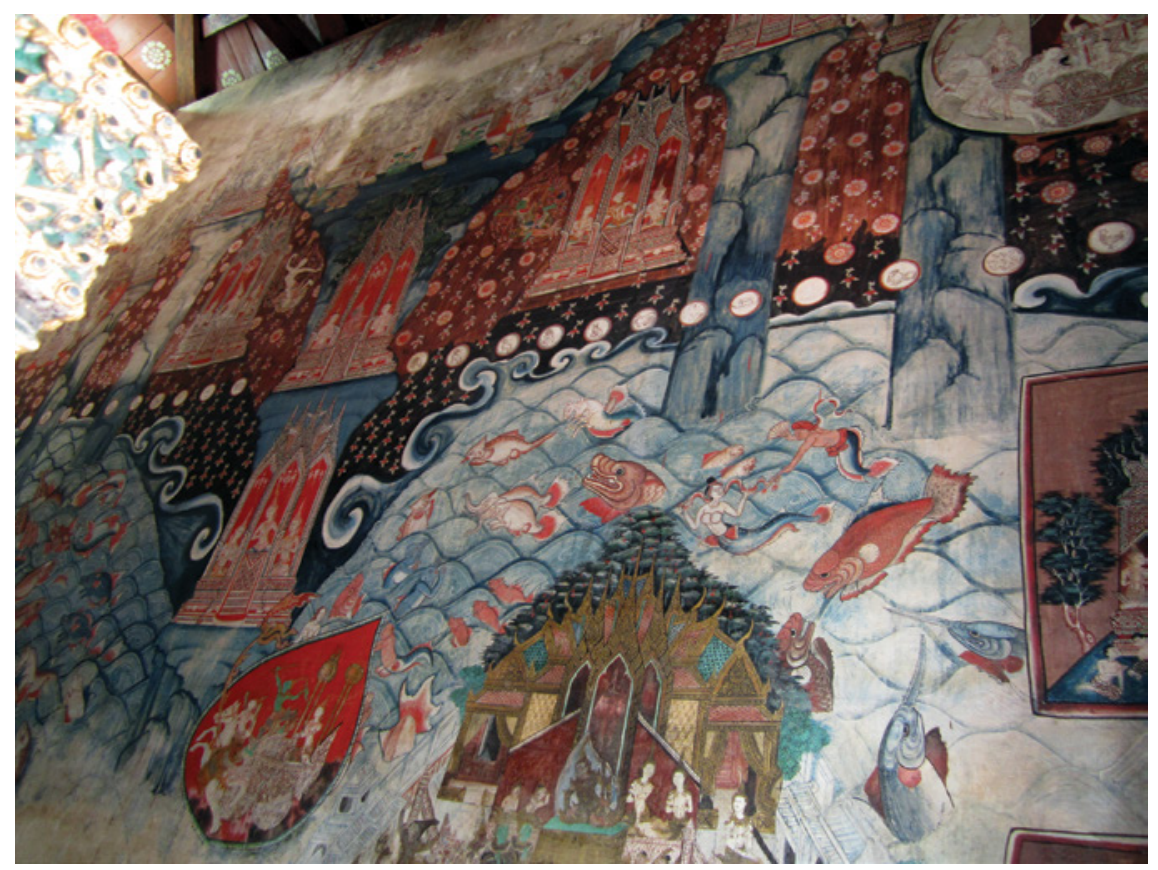

FIGURE 12 The painting of the Tribhumi scene or the scene of the three worlds of the Thai Buddhist cosmology at Khongkharam Temple in Ratchaburi Province 


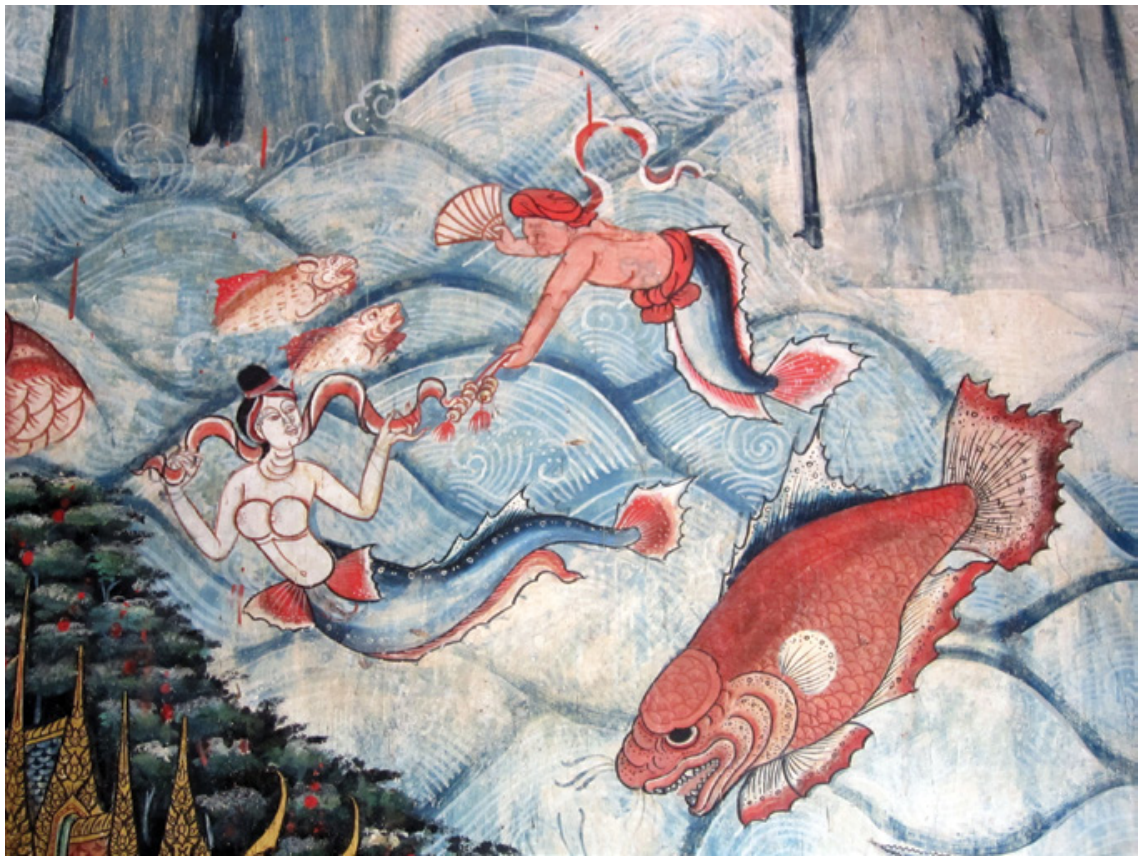

FIGURE 13 Detail of Figure 12: A merman, wearing Indian styled turban among sea creatures of Himavant in the mount Meru, Tribhumi scene behind the presiding Buddha image from Khongkharam temple, Ratchaburi Province.

In the past, the cultural concept of Siamese society classified people under the Buddhist concept of Punna (บุญ—-meritious deeds), Kamma (กรรม—misdeeds), Parami (บารมี— charisma) and Vasana (วาสนา—innate disposition). In painting, differences of class were represented through the physical characteristics of people in several ways such as costume, utensils, skin complexion and manners. A setting in a mural painting is usually divided into 2 main areas of different physical characteristics and symbolic meanings. They are the center and the space outside the frontier. Majestic palaces or temples and the main figures of the depictions are usually located in the center of the picture, representing civilization. In the space outside, there are different minor characters for more imaginary expression. The depictions in this space are called phap-kak (ภาพกาก-minute composition) which illustrate a variety of ethnicities, careers and expressions.

Spaces in the painting accord with the location and the structural compound of the city in Siam. At the center, there were royal palaces and significant places 


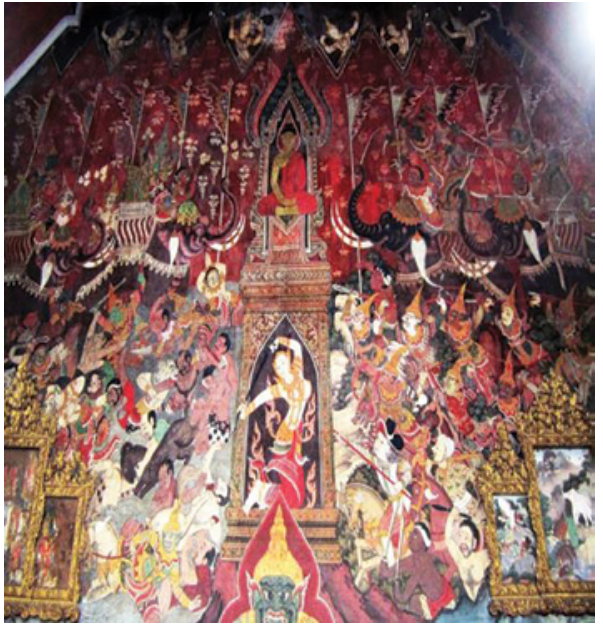

FIGURE 14

The Mara's Impedance: a painting on the wall opposite the presiding Buddha image, above the doorway. Dusitaram Temple, Bangkok

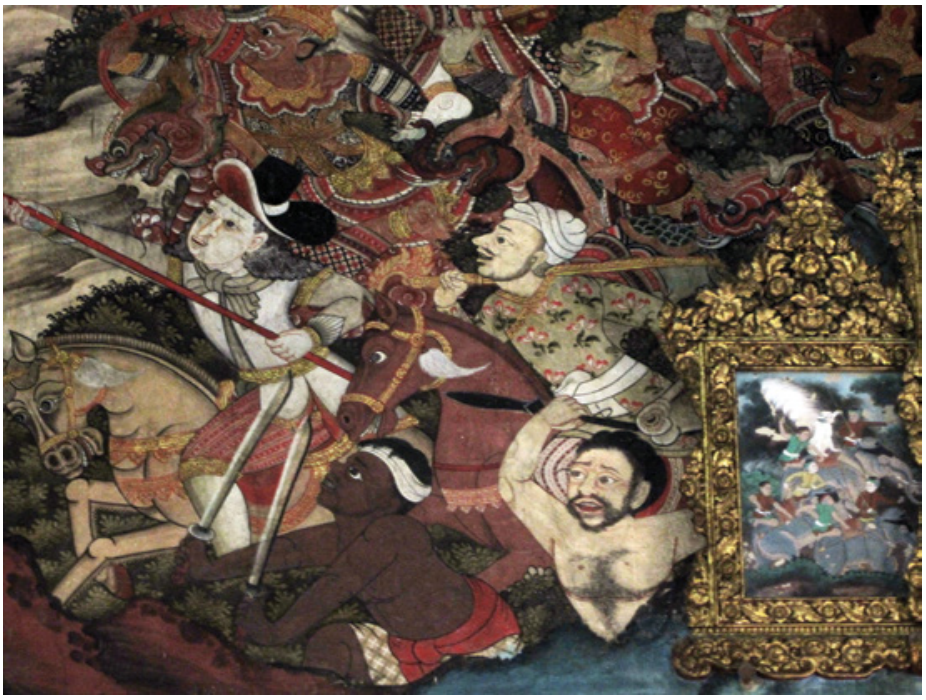

FIGURE 15 Detail of Figure 14. A "khaek" on the horseback as a foreign soldier in Mara's

such as royal temples, forts, surrounded by the palace walls and then the city walls. Outside the city walls, there usually were the plantations and habitations of foreigner communities.

As foreign characters, Muslims appeared in some paintings depicting the life of Lord Buddha, especially in the scene of Mara's Impedance, the scenes from 


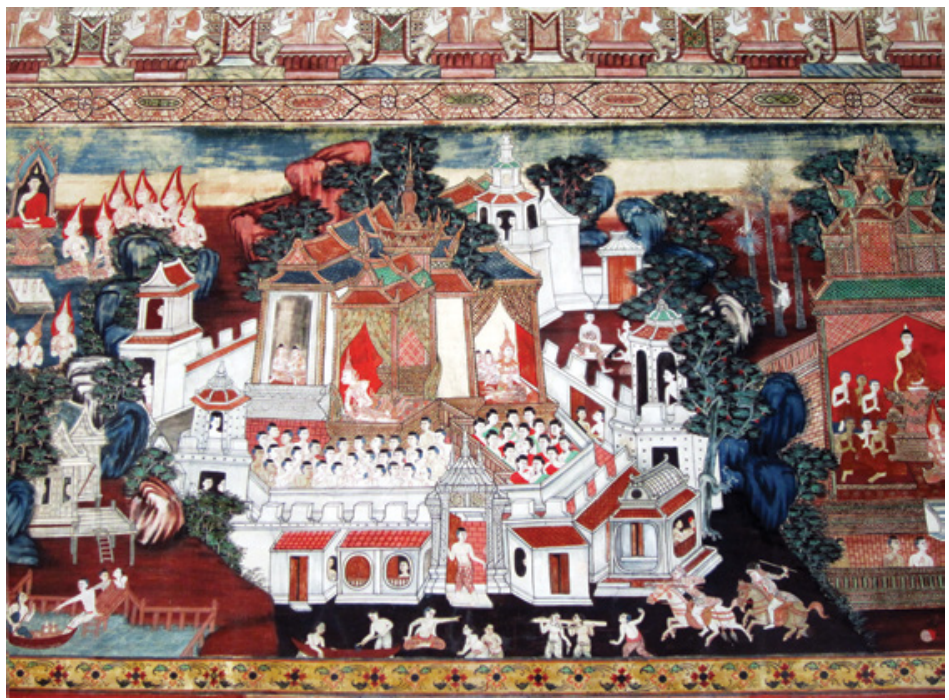

FIGURE 16 A Western equestrian holding sword chasing a Persian soldier outside the city wall. A mural painting from Khongkharam Temple, Ratchaburi province

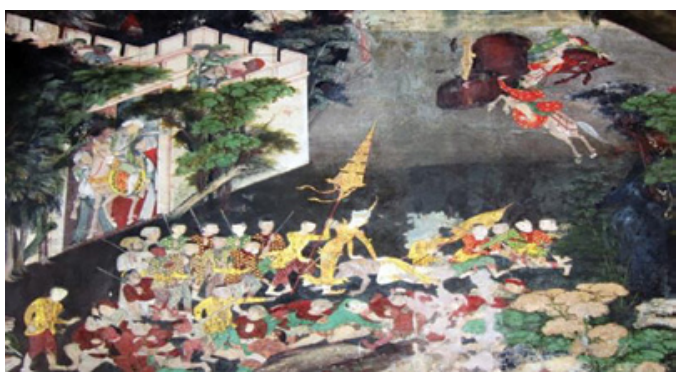

FIGURE 17

A painting depicting Mahosadha Jataka from Suwannaram Temple

Mahajanaka Jataka and Mahosadha Jataka, the Tribhumi scene, the Celestial assembly and the Door guardians.

4 Muslim Portrayals in the Mural Paintings

The content of traditional Siamese paintings may represent some attitudes of Siamese people in different aspects according to the social and environmental contexts. Given Muslim status in historical changes in relation to an 


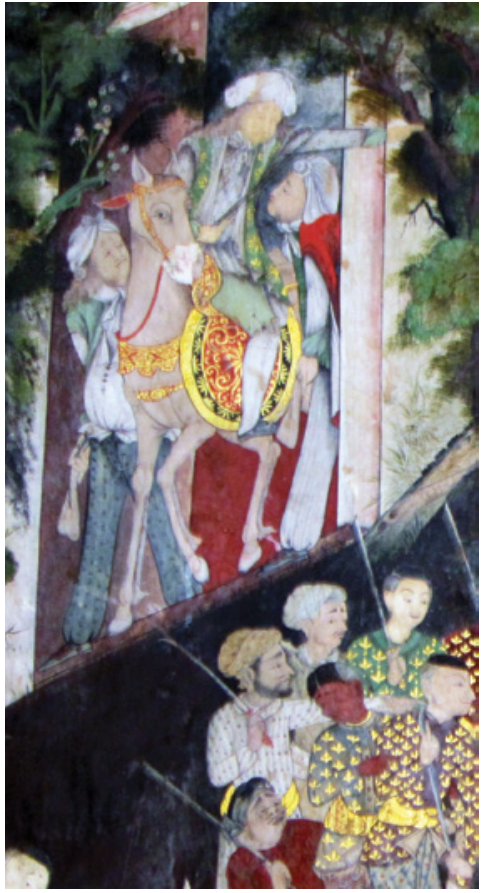

FIGURE 18

Detail of Figure 17: Muslim soldiers wearing headdress

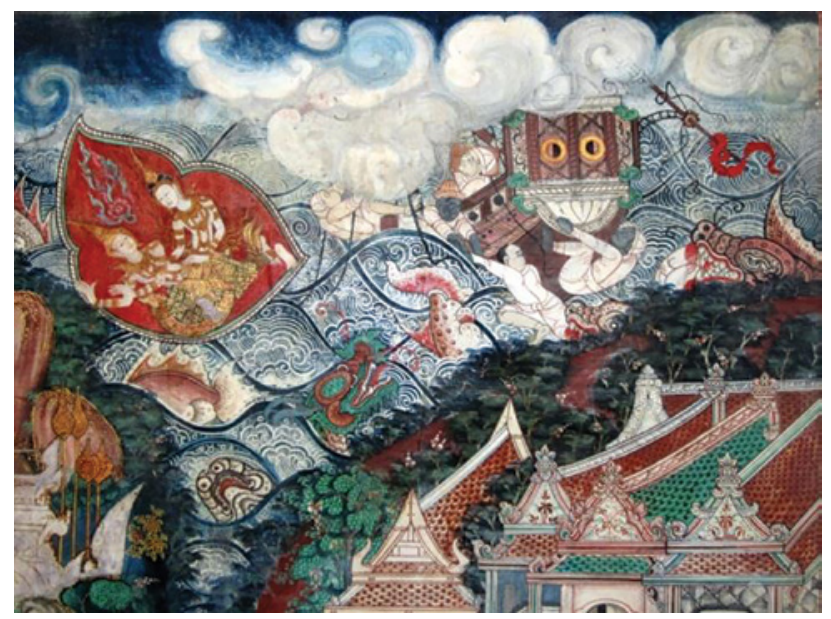

FIGURE 19 A painting depicting Mahajanaka Jataka from Khongkharam Temple, Ratchaburi 


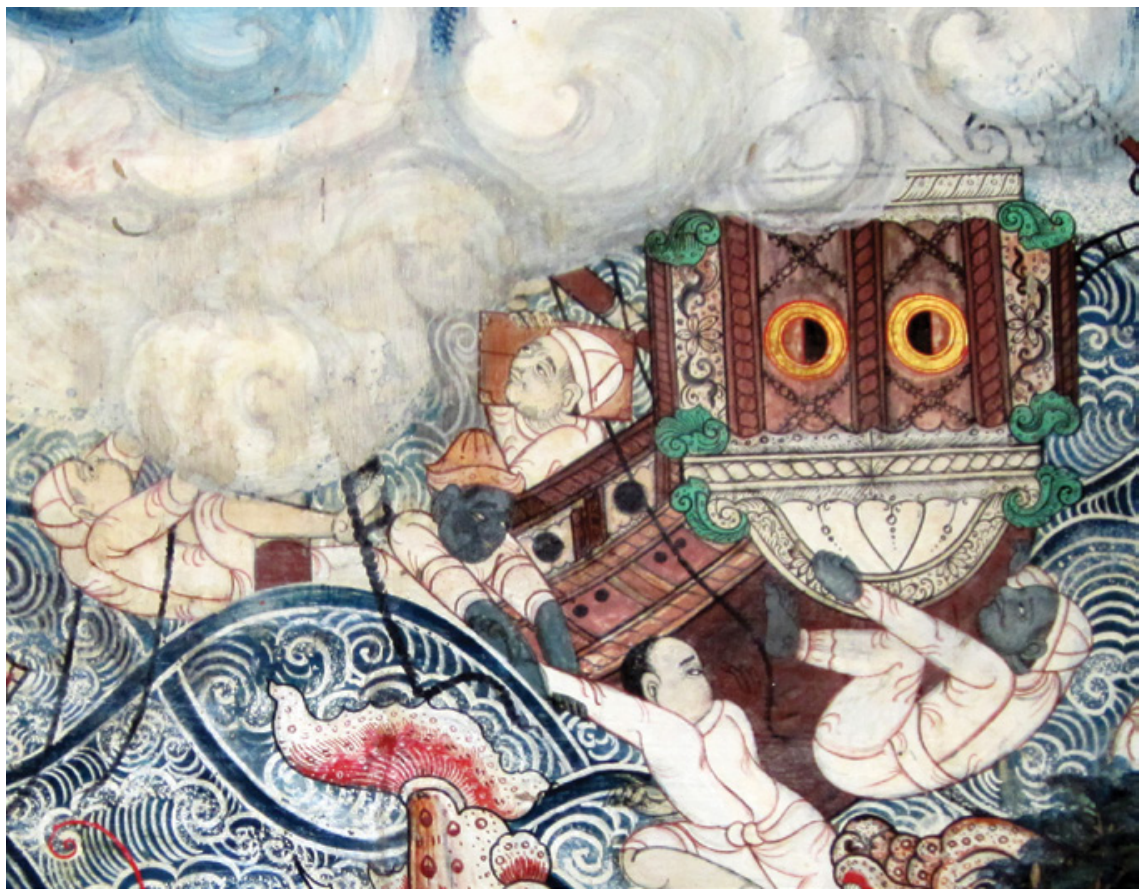

FIGURE 20 Detail of Figure 19: Muslim crew in Mahajanaka's sinking ship

interpretation of the images of Muslims in the mural paintings, this study divides the changing concepts of Siamese people towards Muslims along the dynamic contexts as follows:

1. The otherness of Muslims from afar in late Ayutthaya.

2. The traces of Islamic civilization at the end of Ayutthaya, Thonburi and the Reigns of Kings Rama I-II.

3. The multicultural guests in the Reigns of Kings Rama III-IV.

4. Unity under royal patronage in the Reigns of Kings Rama V-VI.

4.1 The Otherness of Muslims from Afar in the Late Ayutthaya

In the reign of King Songthum and King Narai, Siam became a center of maritime trade that required expertise and connections in the foreign trade network. Muslims from several countries such as Persia, India, Malaya, Java and Cham, therefore, took part in Siamese society in various roles. With distinct characteristics, Muslims were perceived as strangers from different cultural backgrounds. As courtiers, the Persians had the opportunity to present their 


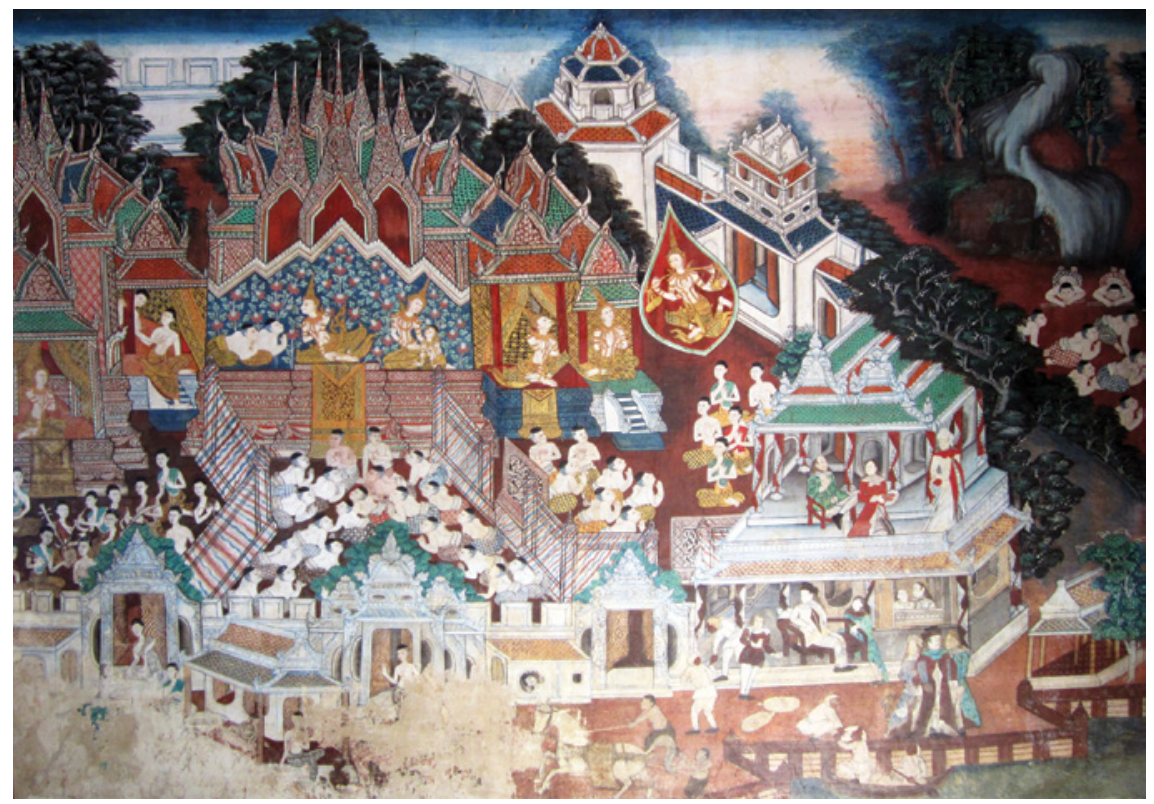

FIGURE 21 A painting depicting Narada Jataka from Khongkharam Temple, Ratchaburi province. Tradesman among the crowd.

culture in traditional costumes, architectural styles, religious rituals and literary narratives. It is recorded that Persian officers narrated the Shah Nameh, a Persian national epic, and the story of the heroic Hamza, the Prophet's uncle, to King Narai (O'Kane, 1972:127).

Besides the images and the attire of Muslim courtiers, the look of Muslim figures magnificently dressed in the illustrations of the narratives and on the craftworks imported from Muslim countries might have inspired Siamese courtiers and their descendants. The artists under their patronage, in turn, portrayed Muslim figures with that impression. Siamese people then considered any non-Buddhists as Michathithi (มิจฉาทิฐิ-misconceiving), Chot Khlao (โฉดเขลา-ignorant) and Dirathi (เดียรถีย-heretical). However, considering the status of Muslims in the social and historical context of those days, these three words are likely to have been applied for Muslims. The images of Muslims in the mural paintings are, therefore, in some ways showing this biased concept. However, an appreciation of the personality and culture of Muslims from the Islamic empire may be gleaned from some portrayals such as the images of elegant Muslim soldiers, wearing turbans, on horseback among other multinational soldiers in the painting of the scene of Mara's Impedance 


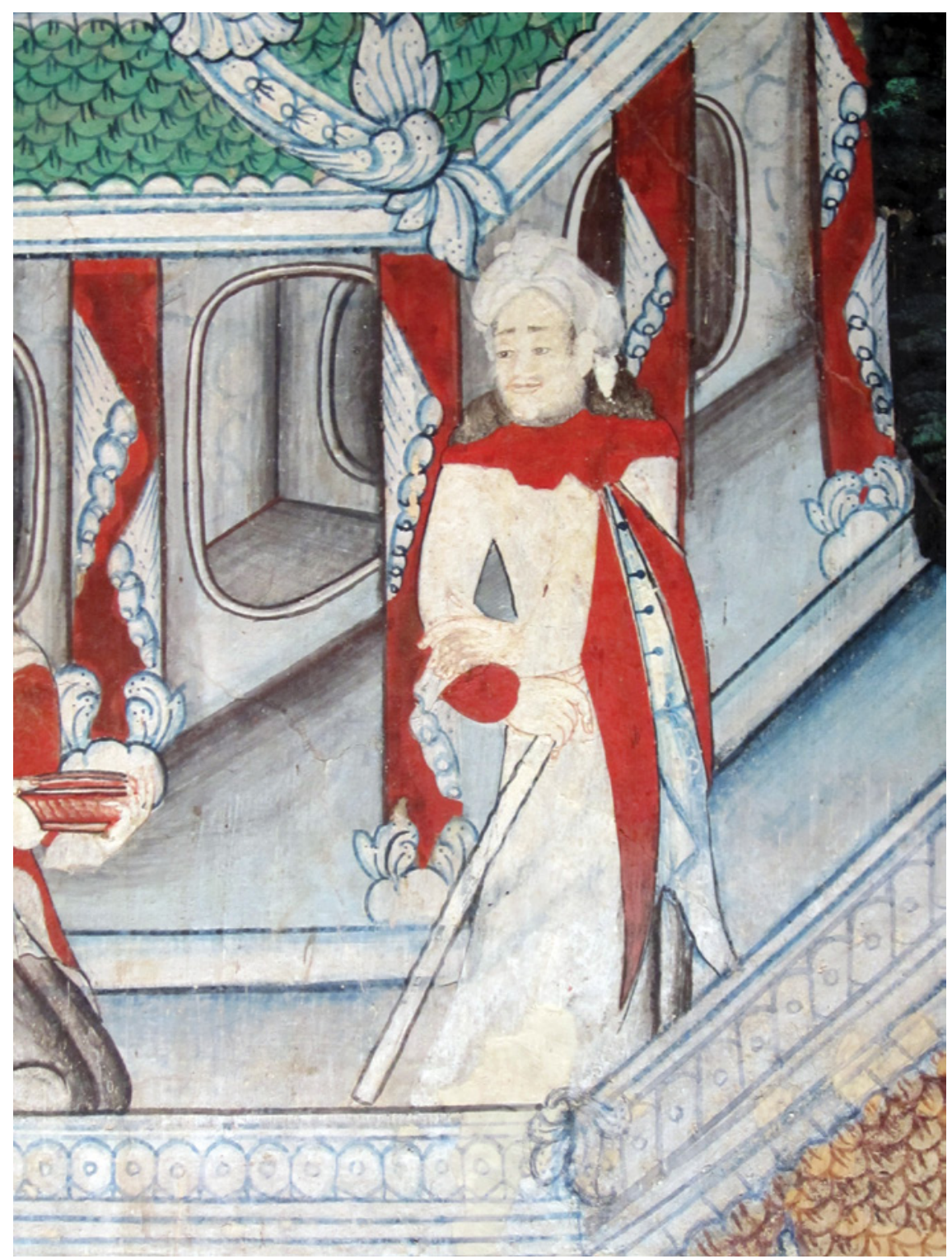

FIGURE 22 Detail of Figure 21: A Muslim tradesman among the crowd. 


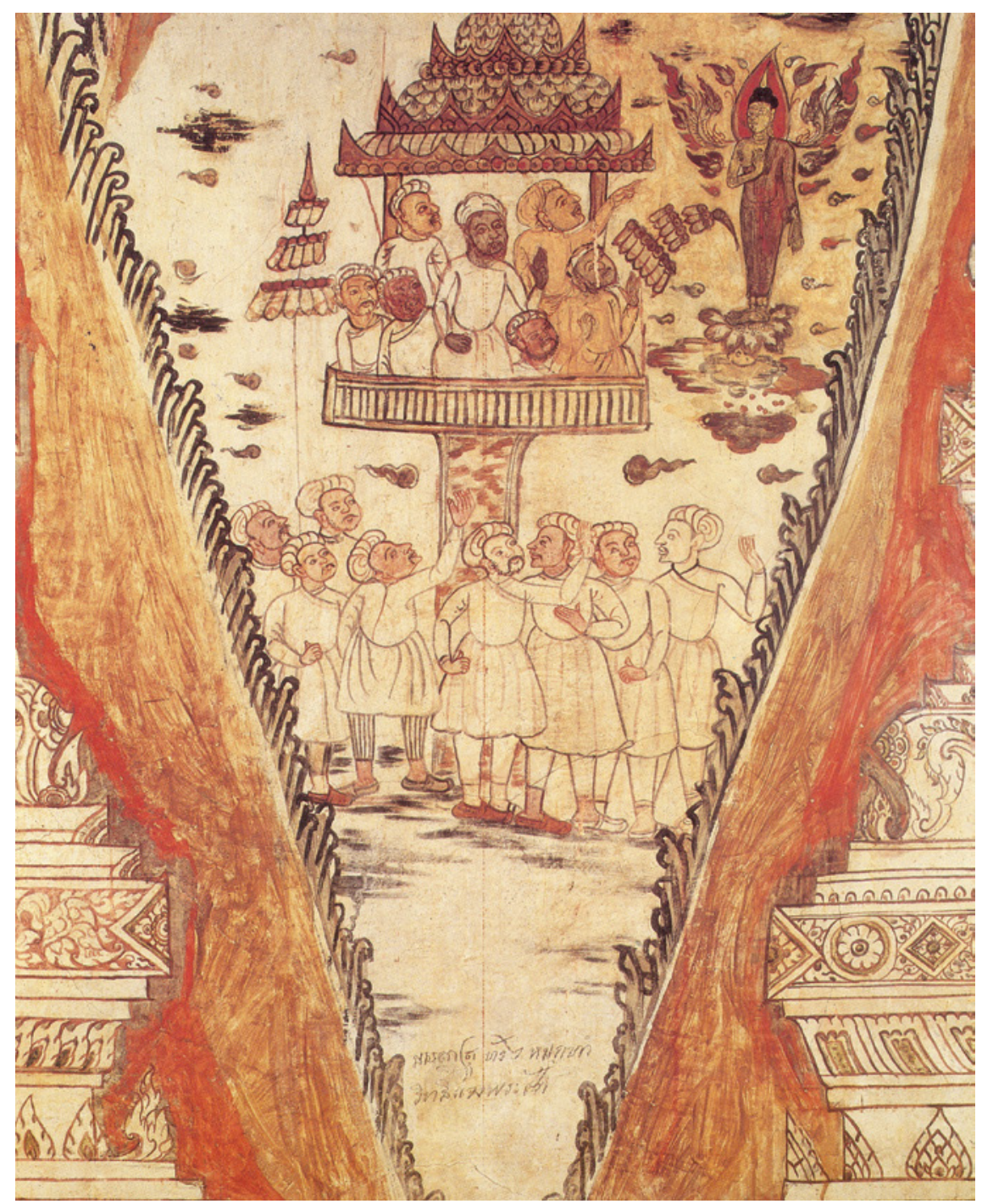

FIGURE 23 Lord Buddha, standing on a lotus flower, displaying a miracle to the heretics, supposedly Muslims. Some of them were on a single pillared pavilion, and the others underneath; from Ko Kaeo Suttharam Temple, Petchaburi province. 


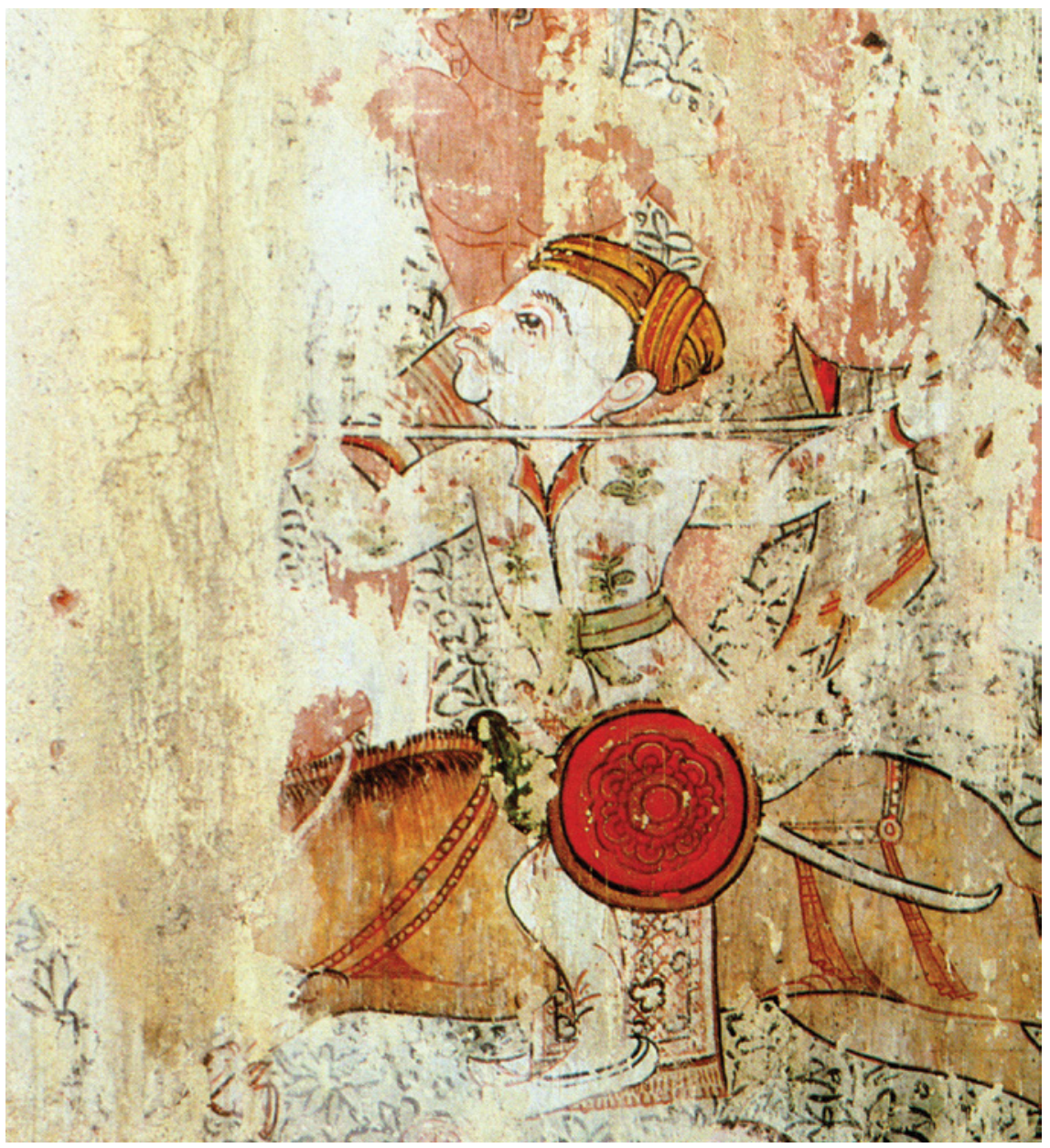

FIGURE 24 A Persian as one of the Mara's followers in the scene of Mara's Impedance; from Chong Nonsi Temple, Bangkok. (Kanokpongchai, 1982: 86)

in Chongnonsi Temple, and Muslims in the royal cavalcade together with other noblemen in Yom temple. These mural paintings may be taken as historical records acknowledging Muslims as a part of Siamese society.

\subsection{The Trace of Islamic Civilization at the End of Ayutthaya, Thonburi and the Reigns of Kings Rama I-II}

In late Ayutthaya, the role of Muslims in the royal court had declined. However, Muslims continued to participate in the development of various aspects of the country, such as trade, politics and culture. Muslims from multi-cultural 


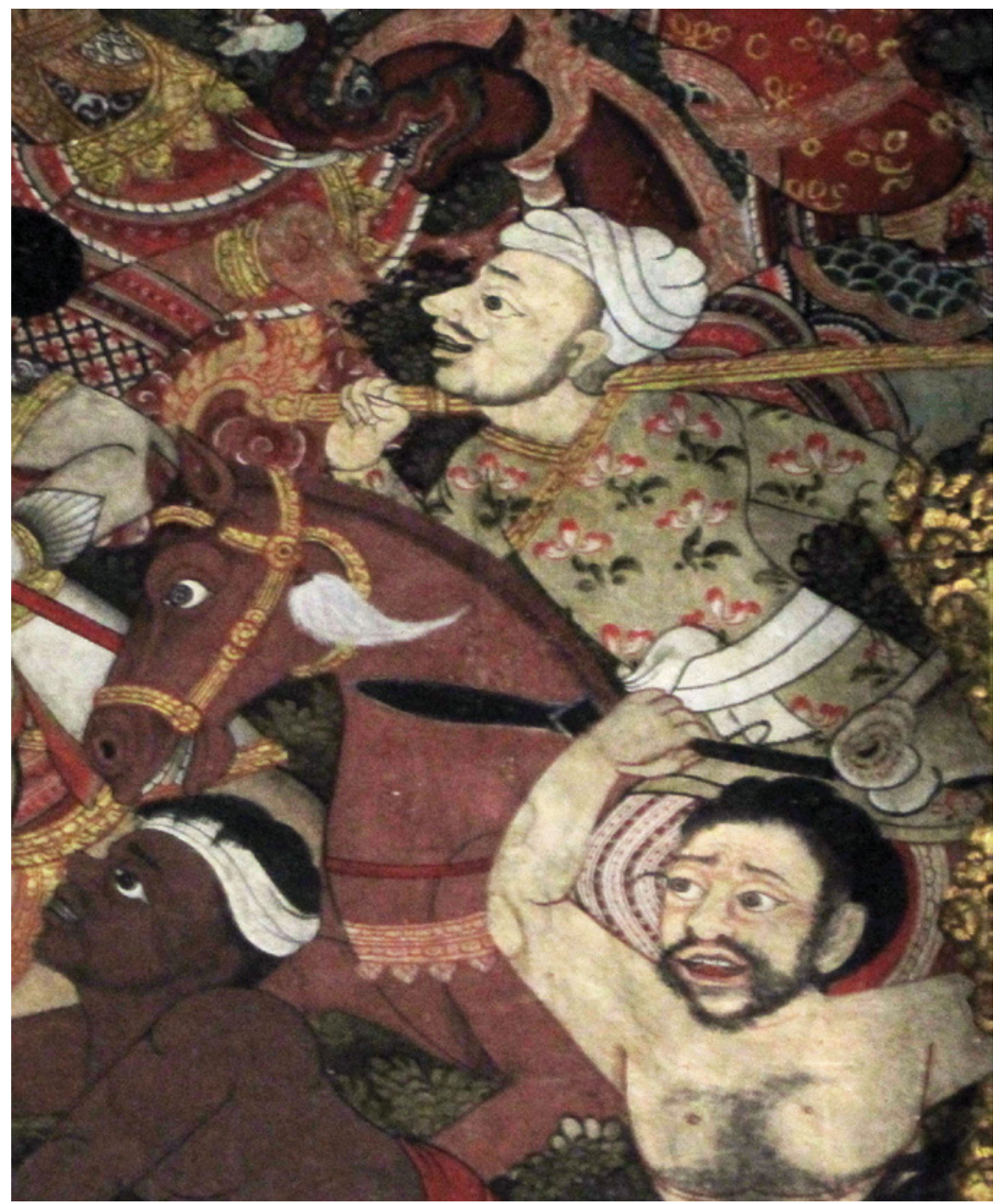

FIGURE 25 A Persian as one of the Mara's followers in the scene of Mara's Impedance; from Dusitaram Temple, Bangkok.

backgrounds such as Cham, Java, Malaysia, Arabia and India who became parts of Siamese society gradually changed their lifestyles according to the local context in so far as they were not against Islamic principles. Information about Muslims such as Islamic belief, Islamic practices and Islamic traditions was gradually acknowledged by Siamese people. 


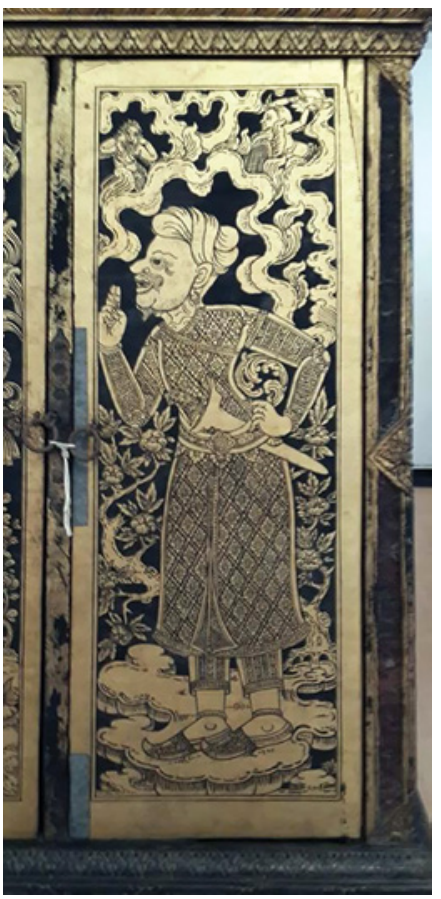

FIGURE 26

Persian King in the painting on the Tripitaka cabinet, Ayutthaya period; from National Museum Bangkok.

The image of a Muslim as one in opposition to righteousness had been passed down over time; as one can see, the image of Mara's retinue in the mural painting of Bangkok temple (Figure 25) is identical to that in the painting of the Ayutthaya period. (Figure 24) Also, the image of Persian door guardians appears in Saket Temple as the awesome guardians replacing the traditional giant and deva. (Figure 27)

\subsection{The Multicultural Guests in the Reigns of Kings Rama III-IV}

In this period, European power had extended over Southeast Asia superseding Muslim countries and China. Considering the need for change, Siam accelerated the development of the country in all aspects, especially in foreign affairs. Information about foreigners was studied as a model of modernity. Images of Muslims were incorporated when depicting many pictures of Western foreigners in the inscriptions and illustrations at the People's University of Phra Chetupon Temple in the collection of illustrations of foreigners in Siam, with descriptions in verses called Khlong Phap Tang Phasa (โคลงภาพต่าง ภาษา). Muslim people-Egyptian, Saracen, Arab, Turkish, Pathan, South Indian, Malay, Cham and Hui were included. Also a collection of Persian tales called 


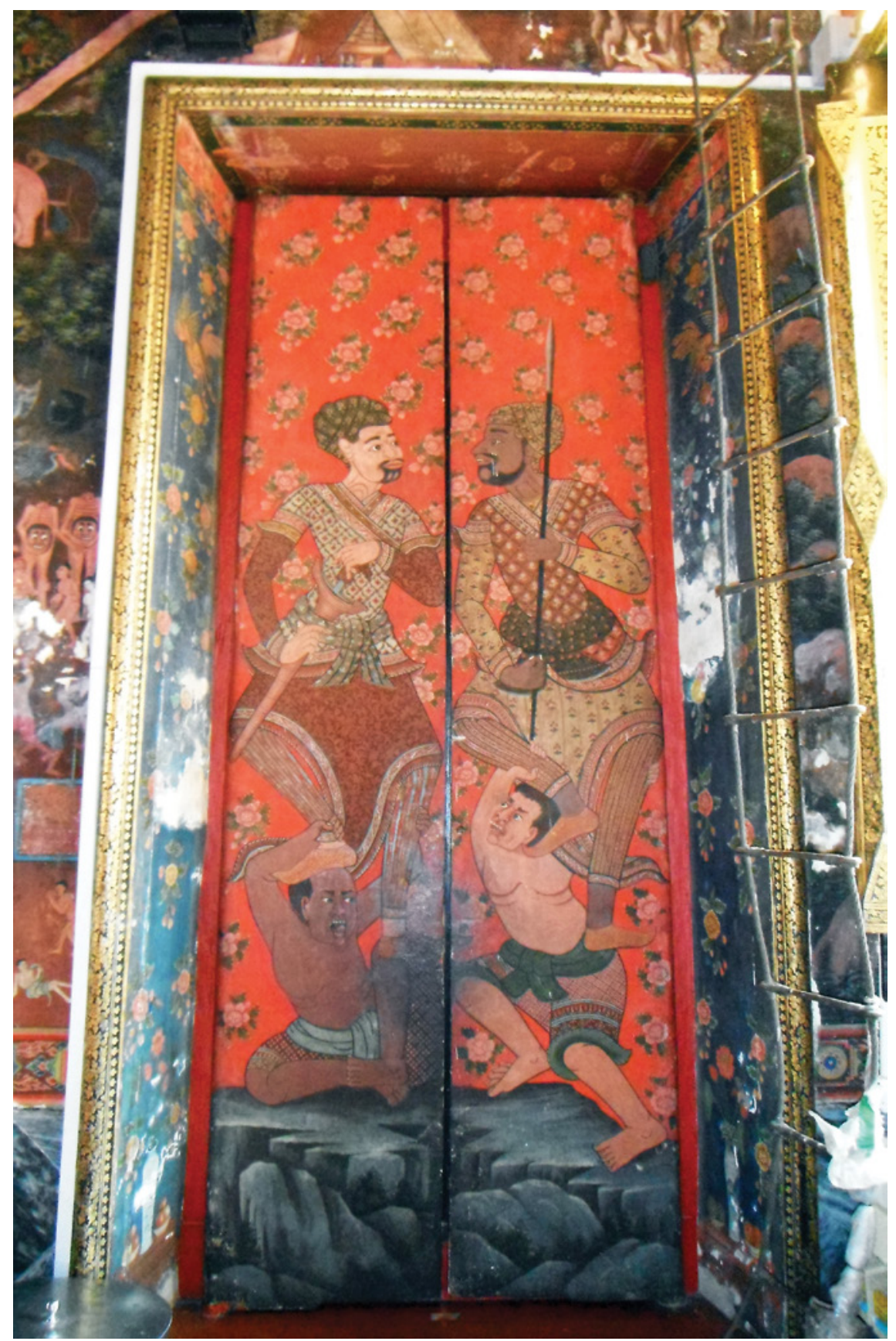

FIGURE 27 Persian door guardians; from Saket Temple, Bangkok. 


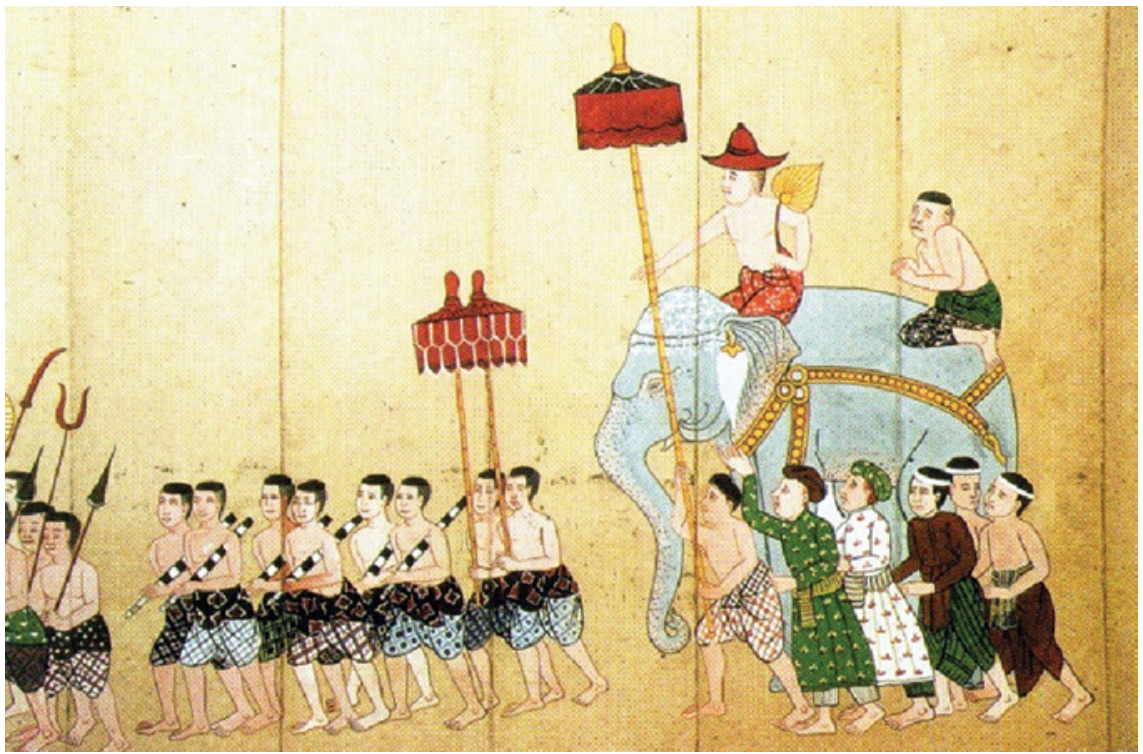

FIGURE 28 Muslim courtiers in a Royal procession (Chaophraya Pra Khlang 2007:274-275).

Nithan Sipsong Liem were inscribed on the wall of this "University". These tales are ethico-didactic stories of good governance as typical in the Persian literary genre called "Mirror for Princes" (Raksamani, 2016:236-240). These inscriptions evidently represent the good status of Muslim in Siam at the beginning of the Rattanakosin Period. They worked in the royal, aristocratic and military services. However, these pictures may depict the idea of the artists that foreigners, such as Muslims, used to be at the service of Buddhist activities.

In this period, the influence of Realism became more significant in the reign of King Rama IV. The stories in mural paintings were partly related to the real situation. The images of local Muslim people in the raft house or Kheak Pae had been illustrated in mural paintings in Kalayanamitr Varamahavihara Temple representing Siamese daily secular life.

In Pathumwanaram Temple, Sa Pratum or Pratum pond which was the peaceful location of the temple had been illustrated to represent the perspective of heaven. The story of folk tales, "Sitanonchai" had been selected to teach people. In the story, the images of luxurious Muslims appeared as guests from overseas while the image of local Muslims in daily life is displayed as a part of the society. 


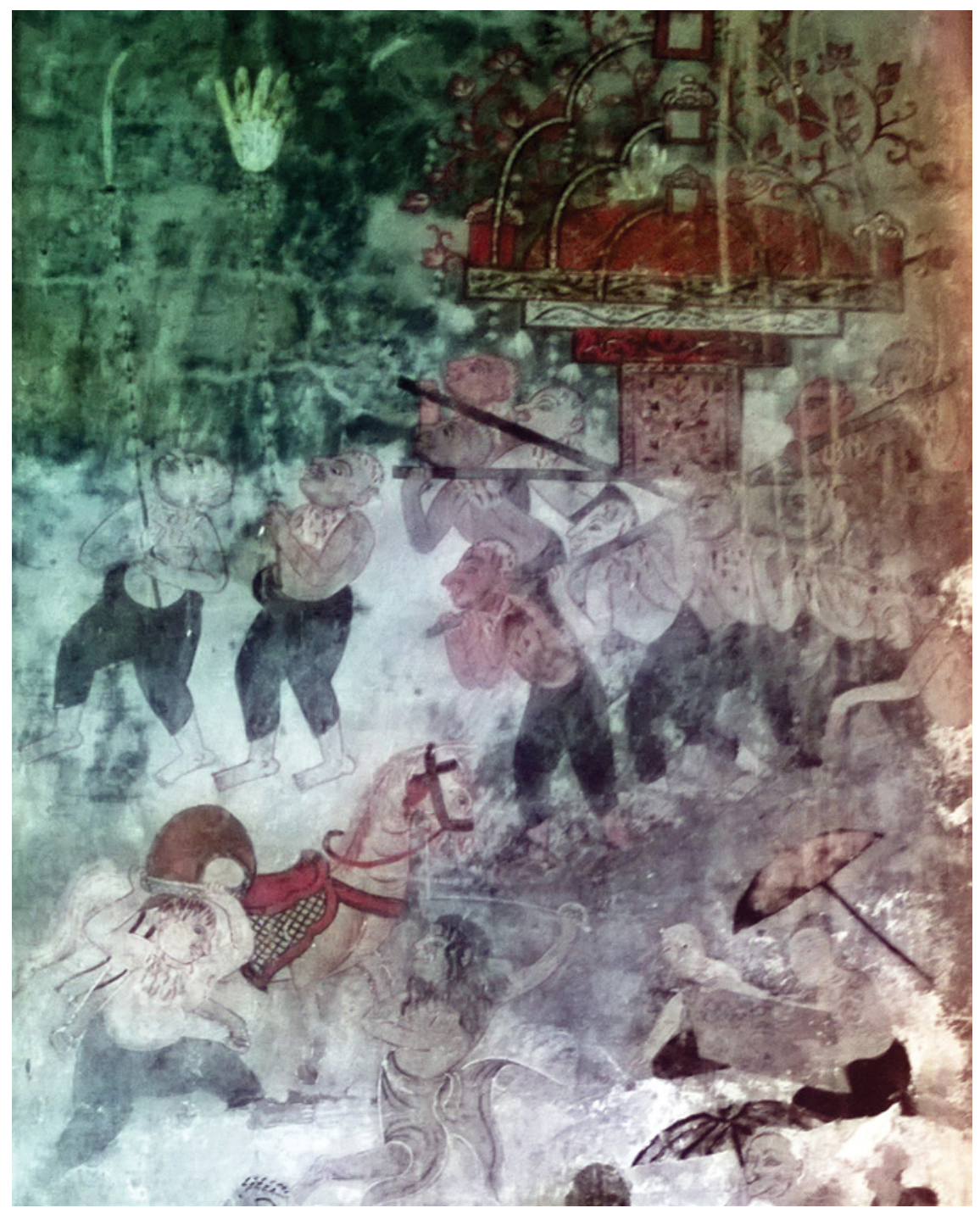

FIGURE 29 Muslim courtiers in a Royal procession (Chaophraya Pra Khlang 2007:274-275).

\subsection{Unity under Royal Patronage in the Reigns of Kings Rama V-VI}

Islamic Kingdoms in the world gradually declined and collapsed during this period after the end of Ottoman Empire in World War I while European countries became powerful. Siam modified the development policy of the country in accordance with the global change. The foreign specialists, including Muslims, contributed to new emerging government agencies that worked more effectively 

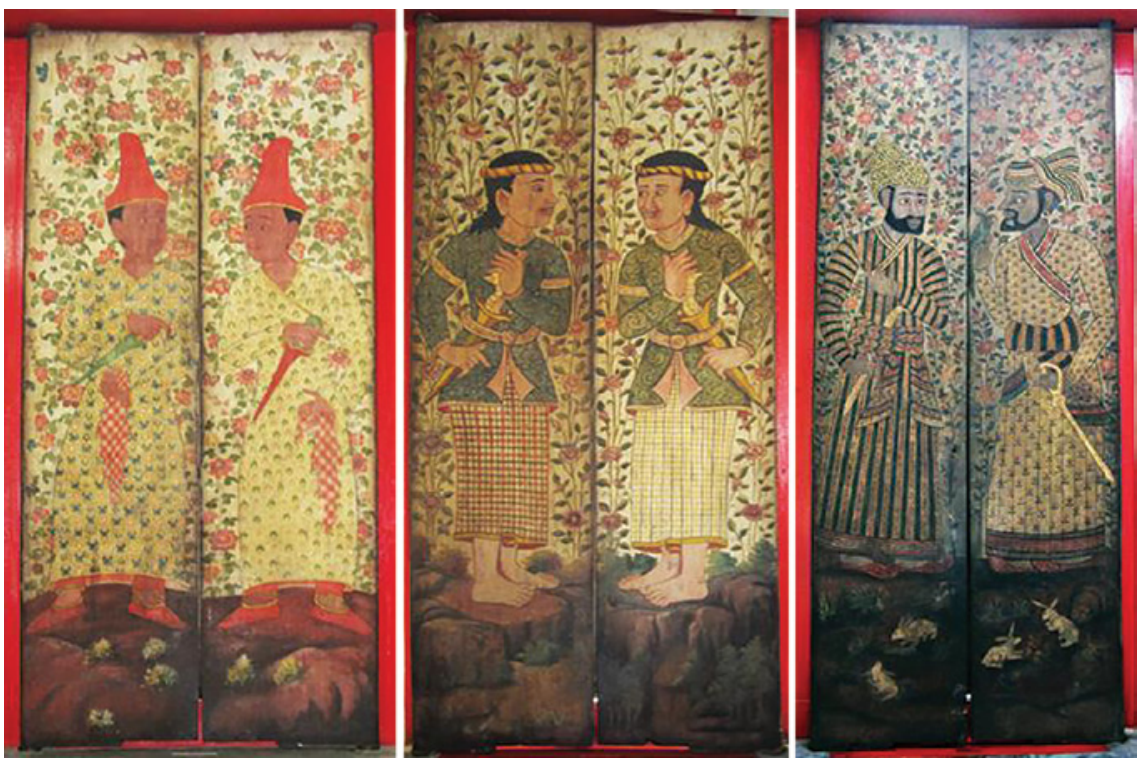

FIGURE 30 Images of people from Muslim lands portrayed on the windows of Phrachetupon Temple, as guardians.[Figure 30a] [Figure 30b] [Figure 30c]

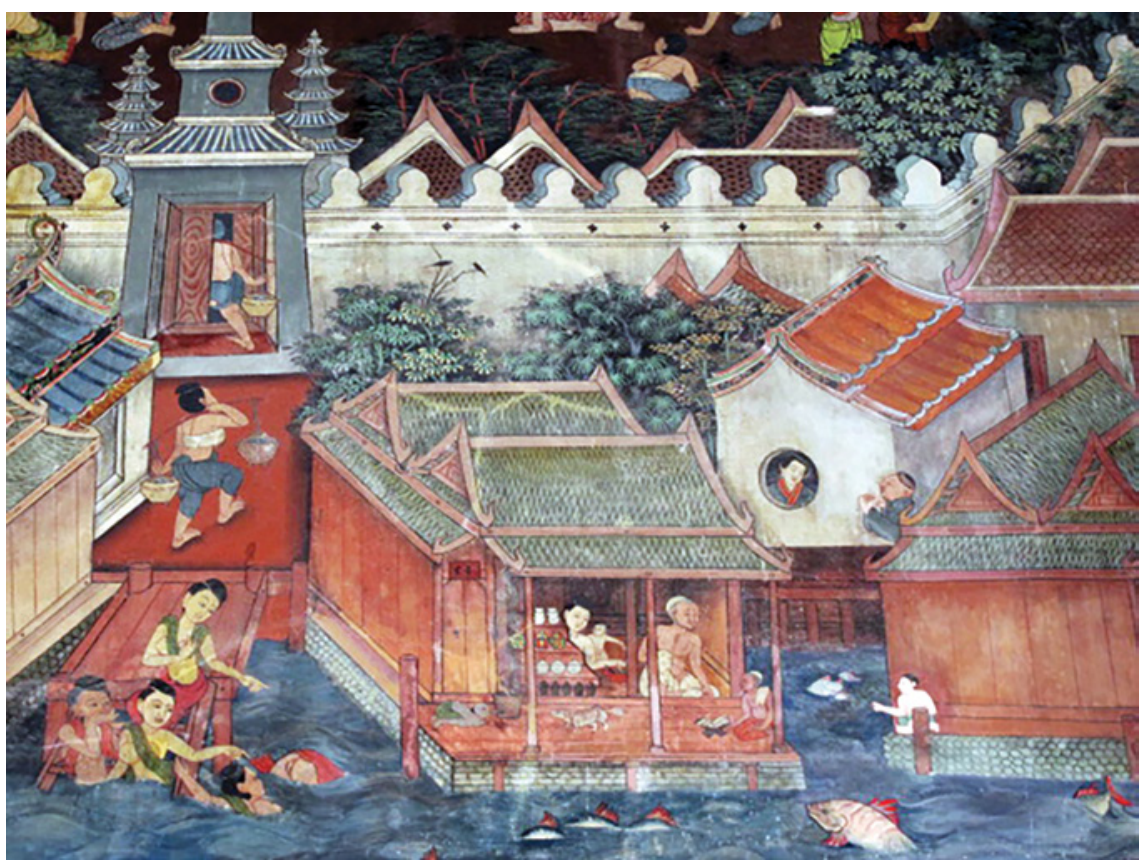

FIGURE 31 A Muslim family's raft-house among a multicultural riverside community; from the mural painting at Kalayanamitra Temple, Bangkok. 


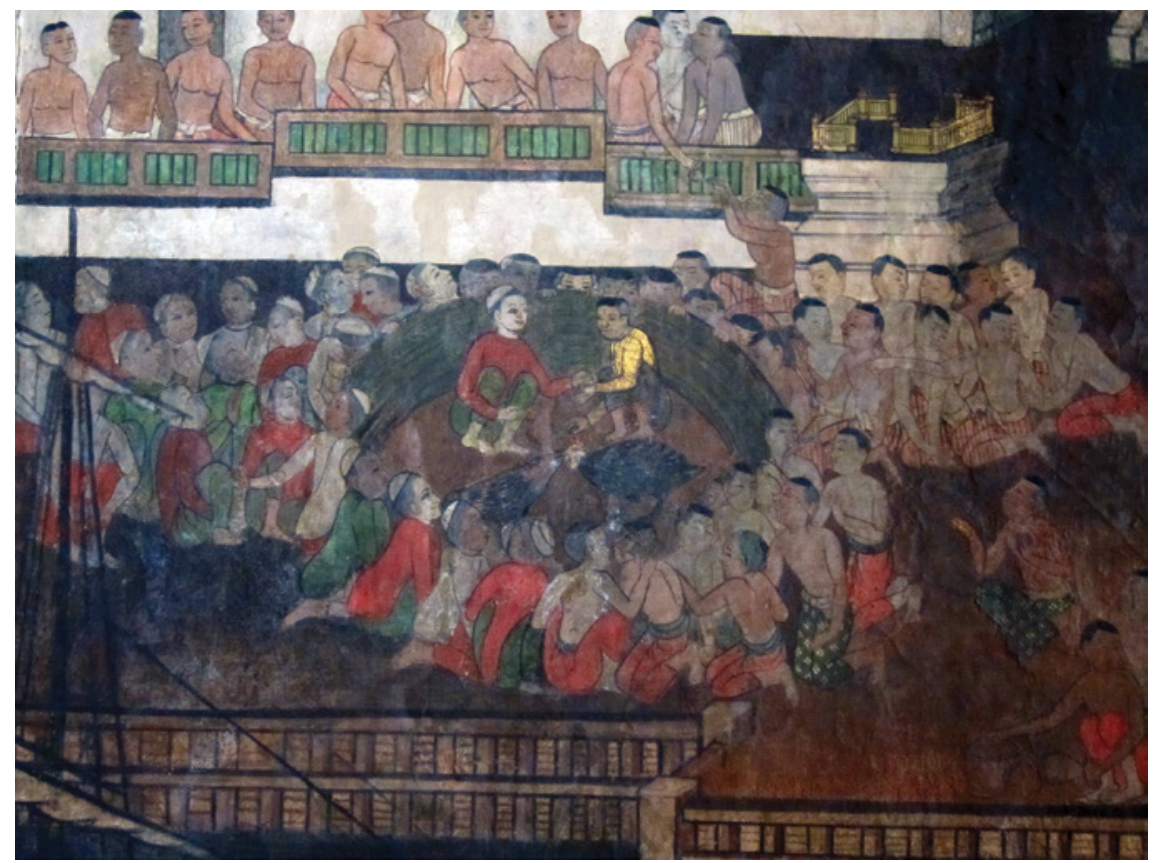

FIGURE 32 Locals from Saiburi wearing Muslim turbans gathering to watch a cockfight between Si Thanonchai (the main character in the tale of Si Thanonchai) and his opponent; from the mural painting at Pathum Wanaram Temple, Bangkok.

in several fields and, likewise, Muslims in Siam significantly contributed to the development of the country. The King, as a great religious patron, took care of the multi-religious Siamese people. People of various religions from several countries became unified under the royal patron. In this period, the role of the mural paintings in the religious aspect in the temple decreased.

The mural paintings on the inside wall of the domes of Anantasamakhom Throne hall depict the history of the Chakri Dynasty. One on the Western dome is the picture of King Rama IV surrounded by priests and men of various faiths; representing the King's patronage of all religions. Muslims are among these people.

\section{Conclusion}

As gathered from the mural paintings from Ayutthaya through the Ratanakosin period, it can be noted that the images of Muslim in the Thai concept were developed at each time and represented the social attitudes of each period. 


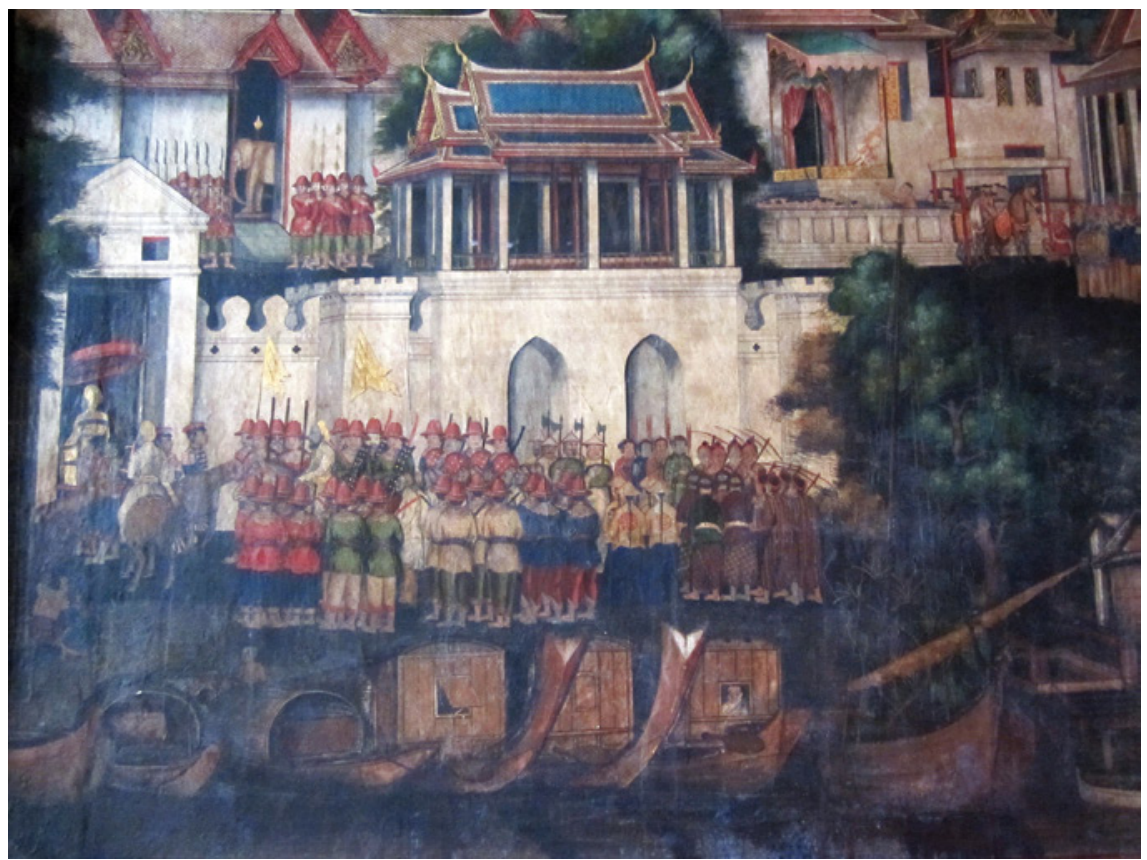

FIGURE 33 A procession of foreigners in Persian costume entering the city gateway; from the mural painting at Pathum Wanaram Temple, Bangkok.

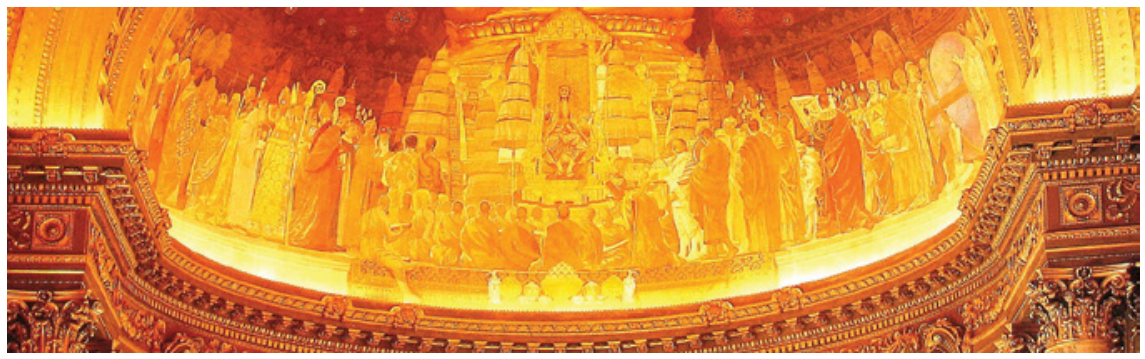

FIGURE 34 The murals under Anantasamakhom Palace dome depicting Muslims from several countries unified under royal patronage as the Pasoknikorn (พสกนิกรpeople of the King). (Committee for the Rattanakosin bicentennial celebration, 1982:254)

\subsection{The Otherness of Muslims from Afar in the Late Ayutthaya}

In late Ayutthaya, Siam was a center of the maritime trade that attracted Muslims from several countries to be a part of the national development. In spite of an appreciation of the personality and culture of Muslims from the Islamic empire Muslims were regarded as the others from afar. They were 


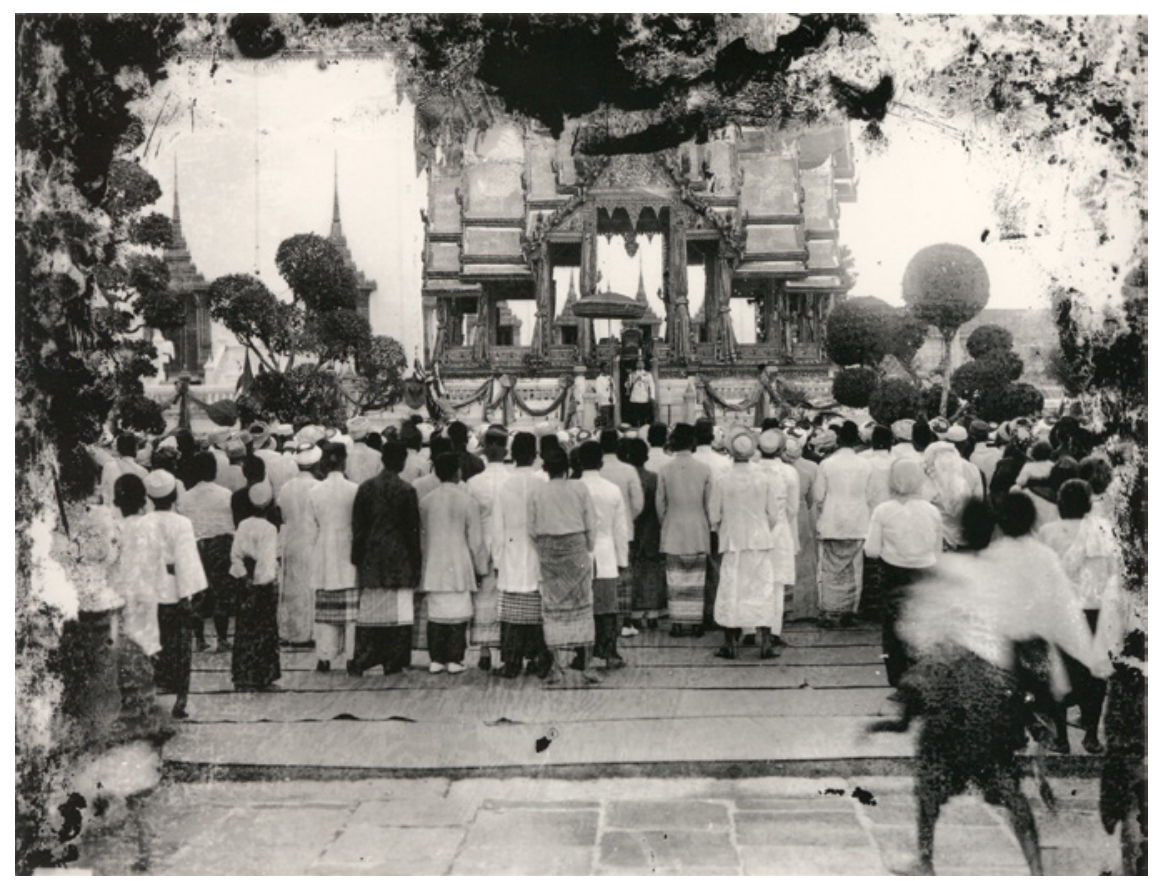

FIGURE 35 Muslim leaders were granted an audience with King Rama vi to receive royal honorable robes and Sajadah or praying carpets. (National archives of Thailand)

illustrated in the mural paintings as strangers who had concepts distinct from the Siamese.

\section{2}

The Trace of Islamic Civilization at the End of Ayutthaya, Thonburi and the Reigns of Kings Rama I-II

During this period, Muslims continued to participate in the development of various aspects of the country such as trade, politics and culture. Muslims from multi-cultural backgrounds became part of Siamese society and gradually changed their lifestyle according to the local context.

Information about Muslims such as Islamic beliefs, practices and traditions were gradually acknowledged by Siamese people. However, the image of Muslims, as passed down over time, was still as opponents of righteousness. In mural paintings, Muslims were symbolically depicted in the Buddhist narration.

\subsection{The Multicultural Guests in the Reigns of Kings Rama III-IV}

In this period, the influence of Realism became more significant. The stories in mural painting were partly related to the real situation. The image of local Muslim daily lives was illustrated in mural painting in the temple as a part of Siamese daily secular life. 


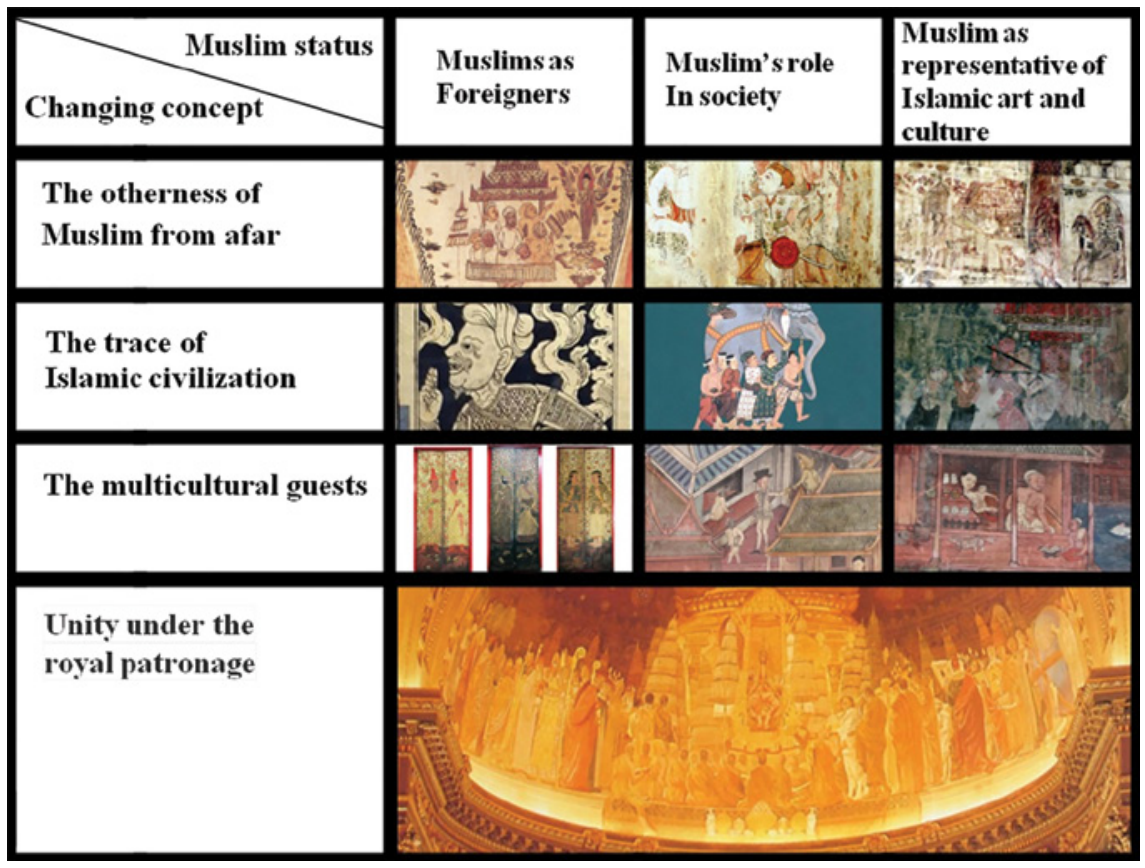

FIGURE 36 The Siamese concepts of Muslims throughtout the periods.

\subsection{Unity under Royal Patronage in the Reigns of Kings Rama V-VI}

In this period, people of various religions from several countries became unified under royal patronage, as depicted in the picture of King Rama IV, the great religious patron, on the mural under the Anantasamakhom Palace dome. It can be said that Muslims then shared the same status in society as other believers.

The concept of "openness to accept each other" and "adaptation on the basis of the differences" may lead to sustainable social development through local wisdom and global change in a holistic way. The assumption of this study may be a guideline for people of different faiths to live together in unity amidst the diversity of people in Thailand.

\section{References}

Blair, S. and Bloom, J. 200o. Architecture in Hattstein, M., and Delius, P., eds. 200o. Islamic Art and Architecture. Cambridge: Konemann.

Canby, Sheila R. 2002. The Golden Age of Persian Art 1501-1722. London: The British Museum Press. 
Chaophraya Pra Khlang (Hon). 2007. Lilit Phayuhayattra Petchphuang, Ed. Manmas Chawalit. Bangkok: Amarin printing and publishing. (in Thai)

Committee for the Rattanakosin Bicentennial Celebration. 1982. Rattanakosin Painting. Bangkok: Fine Arts Department. (in Thai)

Hattstein, Markus, and Delius, Peter, eds. 2000. Islamic Art and Architecture. Cambridge: Konemann.

Kanokpongchai, Sangarun. 1982. Wat Chong Nonsi. Bangkok: Muang Boran. (in Thai)

Khalili, Nasser D. 2008. Visions of Splendour in Islamic Art and Culture. London: Worth Press.

Marcinkowski, M. Ismail. 2002. The Iranian-Siamese Connection: An Iranian Community in the Thai Kingdom of Ayutthaya. Iranian Studies, 35(1/3), 23-46. Retrieved from http://www.jstor.org/stable/4311436.

Niewohner, E. 2000. Decorative Arts. In Hattstein, M., and Delius, P., eds. 2000. Islamic Art and Architecture. Cambridge: Konemann.

O'Kane, J. 1972. The Ship of Sulaiman. London: Routledge \& Kegan Paul.

Raksamani, A. 2014. A Study of Siamese Concepts of Muslims through the Mural Paintings (Research Report), Bangkok: The Thailand Research Fund, Office of the higher Education Commission and Kasem Bundit University. (in Thai)

Raksamani, K. 2016. Wiwitwarapraphan. Bangkok: Department of Oriental Languages, Silpakorn University. (in Thai) 